\title{
Tectonics of the Wysoka Kamieńska Graben (NW Poland) and implications for fault sealing potential
}

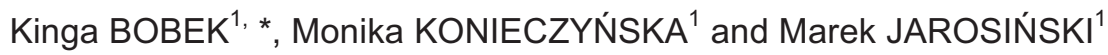 \\ 1 Polish Geological Institute - National Research Institute, Rakowiecka 4, 00-975 Warszawa, Poland
}

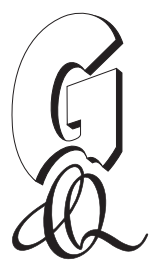

Bobek, K., Konieczyńska, M., Jarosiński, M., 2021. Tectonics of the Wysoka Kamieńska Graben (NW Poland) and implications for fault sealing potential. Geological Quarterly, 65: 38, doi: 10.7306/gq.1607

Associate Editor: Piotr Krzywiec

Reservoir confinement by faults is important for safe storage of liquid waste or hydrocarbons. Having access to 3D seismic and borehole data, we have interpreted the tectonic setting of the Wysoka Kamieńska Graben (WKG) in the NW part of the Polish Basin and subsequently made an interpretation of the sealing potential of the graben-bounding faults. The formation and development of the graben in the Late Triassic and Early Jurassic was controlled by mechanical decoupling in the salts of the Zechstein Group. The primary tectonic factor triggering the graben origin was dextral strike-slip movement along the regional fault zone in the Paleozoic basement, transtensional accommodation of which in the Zechstein-Mesozoic cover led to development of a horse-tail pattern of grabens. During the Late Cretaceous, the graben underwent minor tectonic inversion. Sealing potential analysis of the graben-bounding faults was performed for the Triassic-Jurassic sequence including juxtaposition seal and fault gouge seal components. Finally, we have focussed our interpretation on the Jurassic sequence where the best reservoirs have been recognized. Our results indicate good to moderate sealing potential of the Hettangian reservoir, poor to moderate sealing of the Pliensbachian reservoir and lack of sealing of the Bajocian reservoir. Hence, the Hettangian reservoir, characterized by large thickness, low clay content and a large regional extent, acts as a potential storage formation, being confined by the graben-bounding faults of the WKG.

Key words: tectonic graben, salt decoupling level, underground storage, fault seal potential, geological modelling.

\section{INTRODUCTION}

Based on industrial 3D seismic and borehole data, we have analysed the structure and evolution of the Wysoka Kamieńska Graben (WKG; Dadlez, 1989; Dadlez et al., 1997) located in the northern part of the Mesozoic Polish Basin. The results of tectonic analysis have been used for the assessment of fault sealing potential for hypothetical storage. At this stage of the analysis, we have not specified substances to be stored in this graben. Results of such general analyzes can be useful in regional planning at the site screening stage of storage localization (Delpart-Jannaud et al., 2013).

As industrial development grows, so does the interest in subsurface storage of usable or waste gases and liquids, for which limited places with adequate storage conditions exist at the earth's subsurface. In Poland, the largest storage capacity is provided by deep saline aquifer structures (Wójcicki et al., 2021). The basic terms of use of such aquifers for storage are preferential pressure and temperature conditions keeping the

\footnotetext{
* Corresponding author, e-mail: kbob@pgi.gov.pl
}

Received: January 29, 2021; accepted: June 18, 2021; first published online: August 18, 2021 fluid in a proper state and good sealing that prevents leakage of the stored liquid. Therefore, such aquifers should have an effectively sealing overburden and be laterally confined. The best and most common caprock lithologies are evaporites and shales with a high clay content (Downey, 1984; Grunau, 1987). The lateral confinement of a storage site is often created by convex upward structures like anticlines, preferentially brachyanticlines forming closed domes, or fault planes having good sealing properties. In our study, we consider storage options in Jurassic strata within the WKG located in northwestern Poland (Fig. 1). In this context, the fundamental question is the sealing capacity of the graben-bounding faults. In the region investigated, geological and geophysical data have been collected during exploration for and exploitation of hydrocarbons.

In our fault sealing potential analysis, we do not go into details of storage characterization, such as a depth, structure capacity, or quality of aquifers and seals. We assume generally that the potential storage formation ought to be a thick sandstone aquifer with sealing units at the top. In the Polish Lowlands, one of the preferential storage options is provided by the Lower and Middle Jurassic aquifers and seals (FeldmanOlszewska et al., 2010, 2012). This storage system has been also selected for the WKG, for which the sealing property of faults is a major concern.

Numerous studies have recognized faults as one of the important factors controlling the sealing of hydrocarbon reservoirs 

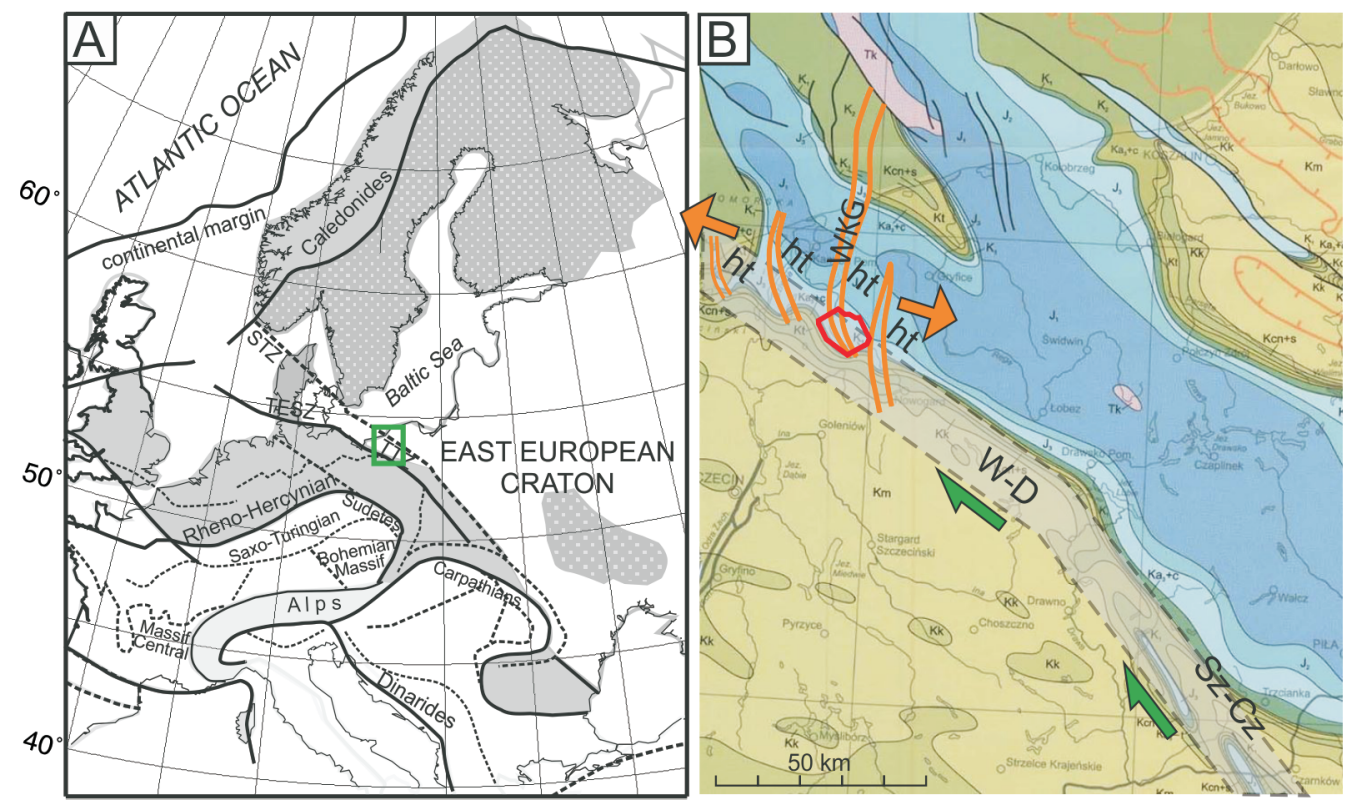

Stratigraphy

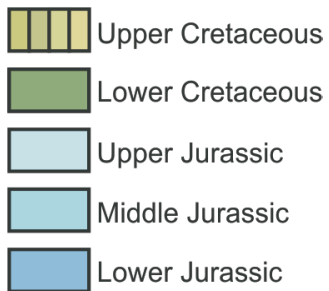

Fig. 1A - the regional context of the study area within a tectonic sketch of Central Europe (after Jarosiński et al., 2006); B - the study area (red box) located above the Wysoka Kamieńska Graben (WKG) on a geological map without Cenozoic (after Dadlez et al., 2000), with the postulated Wolin-Drawsko (W-D) basement fault zone, the Szamotuły-Człopa salt diapir array (Sz-Cz) and the horse-tail grabens (ht) in the Mesozoic cover, the dextral strike-slip movement interpreted at the basement fault zone (green arrow) and secondary extension of horse-tail grabens (orange lines and arrows) are marked

and their behaviour during production (e.g., Bredehoeft et al., 1992; Knai and Knipe, 1998; Moretti, 1998; Aydin, 2000). The fault seal potential is a technical problem relevant to reservoir engineering studies, but it concerns also many geological processes in which fluid flow through the sedimentary successions is important. Fault seal is more or less directly related to diagenesis, compaction coupled with overpressure, and the expulsion and migration of hydrocarbons (Watts, 1987; Pei et al., 2015). Therefore, fault seal potential should be integrated within basin modelling studies (Knott, 1993; Knipe, 1997; Fisher and Knipe, 1998). Fluid conduction within brittle fault zones is also related to tectonic loading. Episodes of fault activation may make their surrounding zones more conductive (Knipe, 1993; Chen et al., 2013). Also, critically stressed faults under present-day load conditions show increased conductivity for fluids (Barton et al., 1995; Mildren et al., 2002; Zoback, 2007). However, the sealing property of faults depends also on their heterogeneous structure, which is also difficult to characterise by geological data. Petrophysical and geomechanical parameters characterizing fault zones are rarely available and, if so, only for a small portion of a fault surface. The heterogeneity of fault zones has a scale smaller than the detection capabilities of geophysical techniques. This is a reason why, despite persistent interest by the oil industry, the determination of fault sealing properties remains a challenge.

To adjust the solution of this complex problem to the quality of the available dataset, it has been simplified. In common industrial practice, two fault sealing components are usually defined: (1) juxtaposition of the reservoir unit across the fault plane with poorly permeable strata (Smith, 1966; Weber, 1997; Fisher and Knipe, 1998; Yielding et al., 2010); and (2) the fault zone itself filled with impermeable fault rocks (Watts, 1987; Foxford et al., 1998; Pei et al., 2015).

The juxtaposition component of the fault seal potential is related to the cross-fault contact of permeable and impermeable rock units. In practice, the storage body in clastic rocks often has a "layer cake" structure of repeated reservoir and sealing units represented by sand and shale respectively (Watts, 1987; Fulljames et al., 1997). However, at an early stage of site recognition, the permeability is usually not sufficiently controlled, and so the juxtaposition seal is often evaluated based on the lithological differences. As a result, a simple assumption of permeable sandstone layers and sealing shale or evaporites is often assumed. Other lithologies, such as carbonates, need further characterization of the fracture system and rock matrix. In the case of the succession studied, in which shale and sandstone prevail, we do not have direct and reliable information on permeability; therefore, this component can be determined only qualitatively.

The fault gouge component (membrane seal) is developed based on the assumption that, due to fault displacement, the clay and mud fractions of the host rock are incorporated and smeared into the fault gouge (Gibson, 1994; Vrolijk et al., 2016). Detailed study of fluvial-deltaic sandstones and shales (Lindsay et al., 1993), lithified and displaced by faults in relatively shallow basin conditions, has enabled the recognition of three mechanisms of rock mixing by faults. (1) Abrasion, where the shale host rocks are disintegrated and abraded by the initial fracture failure and its roughness; (2) shearing, where the shale particles are disposed within a simple shear zone (cataclasis), and (3) injection of clay components from host rock due to their fluidization. In our study, the Lower Jurassic sequence was deposited during fault displacement that indicates shallow conditions when the fault zone formed. At a depth range of a kilometre, where the clastic rocks were only initially consolidated, sorting and redistribution of phyllosilicates took place without large-scale cataclasis or grain recrystallization (Knipe, 1992; Walderhaug, 1996; Labaume and Moretti, 2001). Therefore, we can infer that the fault gouge was dominated by simple mixing and smearing of host rock lithologies along the fault zone at a distance related to the fault displacement. In such a simplified case, the fault gouge sealing potential is often defined by the Shale Gouge Ratio (SGR) parameter (Zheng et al., 2000), related to the overall clay mineral content in the strata displaced 
by the fault. This parameter, in turn, is taken after analysis of the volumetric share of clay in the rock, termed the V-shale parameter (Serra, 1984; Hurst, 1987), which is determined from borehole logs and calibrated with laboratory measurements, if available. In our $\mathrm{V}$-shale analyses, gamma-ray logs were used without additional laboratory control on the clay minerals content.

This paper consists of two parts. In the first of them, we describe the tectonics of the WKG and give a genetic model of its formation. The spatial model of the graben, based on 3D seismic data controlled by borehole profiles, is used for an analysis of the throw and compensation of the boundary faults and for calculating the statistics of faults' orientations. The genetic model of the graben is interpreted in the context of the regional tectonic history. In the second part of the paper, we analyze the fault sealing potential with a view to possible storage. Based on borehole logs, we have distinguished units with predominant sealing and reservoir properties. The 3D-fault model constructed with the throws mapped on their surfaces allow us to evaluate the juxtaposition sealing potential component. Further development of the fault model with the results of the shale volumetric share analysis allowed to estimate a fault gouge sealing potential component. Finally, a preferential aquifer, possibly effectively confined within the WKG, has been distinguished.

\section{GEOLOGICAL CONTEXT}

The Mesozoic sedimentary sequences studied within the WKG were deposited in the northern, marginal segment of the Mid-Polish Trough that formed the subsidence centre of the Polish Basin (Dadlez et al., 1997; Stephenson et al., 2003). In a broader view, this basin was a part of the large Southern Permian Basin that stretched from the British Isles to the East European Craton (Ziegler, 1992; Doornenbal and Stevenson, 2010). The WKG structure was formed in the Late Triassic and Early Jurassic (Dadlez, 1989; Dadlez et al., 1997) as one of several similar grabens developed in this region (Fig. 1).

The Upper Permian to Mesozoic stratigraphic sequence starts with the marine Zechstein (uppermost Permian), which comprises three carbonate to evaporite (anhydrite and salt) cycles followed by terrigenous-evaporite lithofacies (Wagner and Peryt, 1997). Storage capabilities are well-documented for the Main Dolomite (Ca2), in which hydrocarbon accumulation was found and exploited since 1979. After extraction of 420 kilotons of crude oil (https://www.salon24.pl/u/wnukowi/799339,zlozeropy-i-koncesja-kamien-pomorski), the field has been recently considered as depleted. The remnant pore space filled with brine may provide low-volume storage or repository options. The Ca2 reservoir seems to be perfectly sealed with rock salt, which allowed an initial (before exploitation) pore overpressure gradient exceeding $16 \mathrm{MPa} / \mathrm{km}$ (Bojarski et al., 1977) to be sustained. However, its small reservoir capacity, and high pressure at a depth of $3 \mathrm{~km}$, may limit its use in practice.

The Mesozoic sedimentary sequence studied was deposited in the marginal part of the Polish Basin. The Lower Triassic deposits are characterized by uniform marine facies across the Polish Basin (Raczyńska, 1987; Gajewska, 1988; Dadlez, 1989). In the WKG region, the Triassic begins with silts and clays (including thin sandstone beds in the Lower Buntsandstein) that pass upwards into oolitic sandstones, siltstones, and claystones, and then into carbonates and sulphates close to the top of the Lower Triassic sequence. The Middle Triassic deposits are dominated by sulphate-impregnated carbonates, passing upwards into marl and shale. In the
Upper Triassic sequence, claystone and mudstone lithofacies are uniform across the basin. In the entire Triassic sequence, the lack of good reservoir properties (high porosity and permeability) excludes effective storage capabilities.

In the WKG the best potential reservoirs are found in the Jurassic. The depositional environments within the Pomerania region generally evolved from terrestrial conditions in the Hettangian and Sinemurian to a more marine environment in the Pliensbachian and again to freshwater in the Toarcian (Raczyńska, 1987; Dadlez, 1989). Due to the significant diversity of sedimentary environments, such as deltas, embayments, shoreface, and offshore (Pieńkowski, 2004), sand bodies do not correlate across the basin. In the vicinity of the WKG, the Lower Jurassic facies may be additionally diversified from the activity of graben-bounding faults with a tendency to preferential accumulation of fluvial sandy deposits within the graben (Pieńkowski, 2004). In the Middle Jurassic, the amount of shale increases up to 50\% (Kopik, 1997, 1998), but sandstone facies are still present. Towards the top of the Middle Jurassic, the content of marls increases, indicating a transition towards the Upper Jurassic carbonates, which are the youngest Mesozoic strata of the study area. The Jurassic sandstones provide preferential storage options within the WKG. Judging from the map (Fig. 1) Lower Cretaceous strata should be present in the western side of the graben. However, they are not documented by boreholes that are clustered around the eastern side of the WKG, and the seismic record neglects the shallower depth interval.

\section{DATA AND THEIR QUALITY}

Our research is based on industrial data acquired during exploration for hydrocarbon accumulations within the $\mathrm{Ca} 2$ of the Zechstein succession. From the point of view of our study that is focused on the storage capabilities of the Mesozoic sequence, the data are somewhat random, being of limited quality and quantity.

The main set of data, obtained from the Polish Oil and Gas Co. (POGC), comprises a 3D seismic survey in the time domain, with nine interpreted seismic horizons. The seismic acquisition completed in 2001 covers the middle segment of the WKG (Fig. 1B). The 3D structural model of the main seismic horizons and segments of major faults (in pillar gridding format) was provided by the POGC. We supplemented this model by interpreting lithostratigraphic horizons tied and correlated to available borehole data. The reconstruction of lithostratigraphic units was completed separately for the WKG interior (hanging wall blocks of boundary faults) and exterior (footwall blocks of boundary faults). Interpreted fault segments have been transferred from Petrel software (Schlumberger) to T7 software (Badleys Geoscience Ltd.) and used to calculate the gridded 3D fault surfaces. At these surfaces, throw maps were constructed and sealing potential analysis was performed using the T7 code which is well-adjusted to faults in clastic successions and widely used by the oil industry for fault seal modelling and hydrocarbon reservoir compartmentalization (Jolley et al., 2010).

The good quality of seismic imaging data from outside the graben allowed the identification and correlation of the following horizons:

$\mathrm{J}_{\mathrm{pl}}$ - a clear negative seismic reflection produced by lithological changes from shaly sandstone to coal-bearing shale in the lower Pliensbachian; 
$T_{m}$ - a positive seismic reflection from the top of the Muschelkalk limestone, representing a change in lithology to the Keuper shales;

$\mathrm{T}_{\mathrm{p} 2}-\mathrm{a}$ strong positive seismic reflection formed below the top of the Buntsandstein;

$\mathrm{T}_{\mathrm{p} 2 \mathrm{t}}$ - a clear negative seismic reflection within the lowermost Buntsandstein related to a sandstone layer between thick shale deposits;

$Z_{\text {str }}-$ a weak negative seismic reflection from the top of the Youngest Salt (Na4) representing the top of the Zechstein succession;

$Z_{3}$ - a strong positive seismic reflection from the interface between the Younger Salt (Na3) and the Main Anhydrite (A3) within the third cycle (PZ3);

$Z_{2}-$ a strong positive seismic reflection from the Older Salt (Na2) and the Basal Anhydrite (A2) interface within the second cycle (PZ2);

$Z_{1}$ - a negative seismic reflection from the bottom of the Main Dolomite (Ca2) underlain by the Upper Anhydrite (A1g) of the first cycle;

$Z_{s p}-$ a strong negative seismic reflection from the bottom of Zechstein Limestone (Ca1) and Lower Anhydrite (A1d) underlain by Basal Conglomerates (Zp1).

Within the graben, seismic horizons are less visible than outside the graben. It is probably due to both tectonic deformation and the highly variable lithologies caused by synsedimentary faulting. Seismic imaging focusing on the deep hydrocarbon reservoirs did not register signals down to $300 \mathrm{~m}$, and only partly covered the depth down to $600 \mathrm{~m}$. This is why the shallower Upper Jurassic and Cenozoic formations are only documented by boreholes.

Interpretation of seismic horizons was constrained by well logs and lithostratigraphic profiles from six boreholes, among which five are located within the WKG (Fig. 2), and one, Wysoka Kamieńska-2 (WK-2), is several kilometres to the east of the graben. The boreholes are clustered along the eastern flank of the central segment of the graben, at a distance of 600-1100 m from each other (Fig. 3). All boreholes located within the graben penetrated the eastern boundary fault at a Lower Jurassic or Upper Triassic stratigraphic level, reaching the $\mathrm{Ca} 2$ at a depth $<3 \mathrm{~km}$ outside the graben. As the result, the complete Jurassic sequence and only the top of the Triassic are well controlled by boreholes within the hanging wall block (graben interior). The entire Triassic sequence was only documented outside the graben by the WK-2 borehole.

All boreholes studied were drilled in 1978-1984, which limits the quality of the wireline logs, recorded in analogue format. Hence, it became necessary to recalculate the gamma-ray logs from counts per minute to API units following the method of Szewczyk (2000). We have unified these profiles, taking into account caliper data to constrain borehole diameter changes that might have influenced the gamma-ray signal. There is a lack of laboratory tests for the gamma-ray profile calibration. The lithostratigraphic units were taken from the borehole documentation in the National Geological Archive and data stored in the Central Geological Database (http://otworywiertnicze.pgi.gov.pl/).

\section{TECTONICS OF THE WYSOKA KAMIEŃSKA GRABEN (WKG)}

\section{THE MAIN TECTONIC FRAMEWORK OF THE WKG}

Although the WKG has been mentioned in several regional studies (Dadlez, 1990; Dadlez et al., 2000), no detailed study of its internal tectonic structure and evolution is available. The
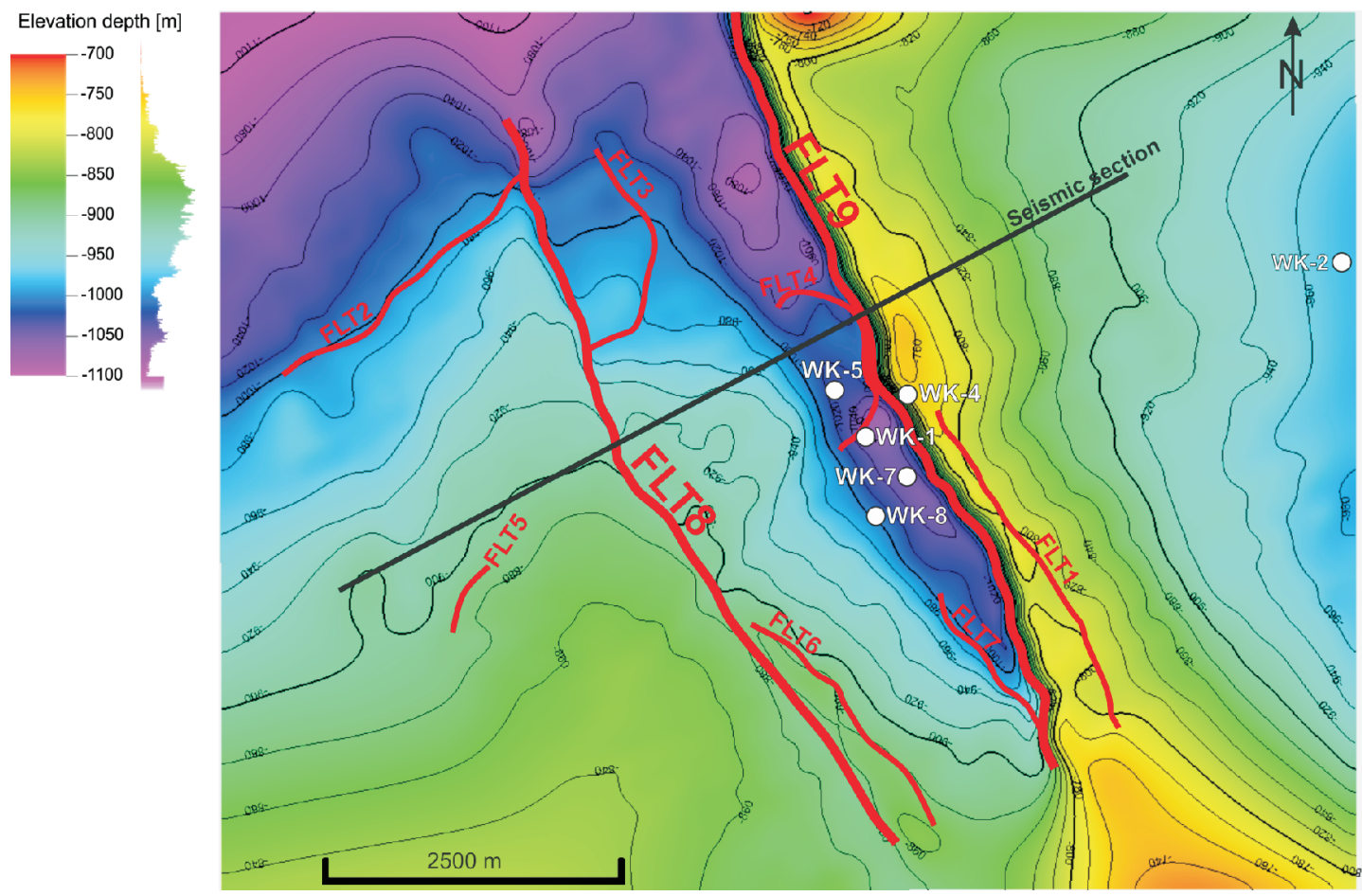

Fig. 2. The map of the Jurassic $\left(J_{p}\right)$ seismic horizon depth showing the asymmetrical graben structure at the Pliensbachian reservoir level

The location of faults (red lines) and analysed boreholes (white dots) are shown; note that the lateral termination of the FLT8 and FLT9 faults is an artefact of data limitation 


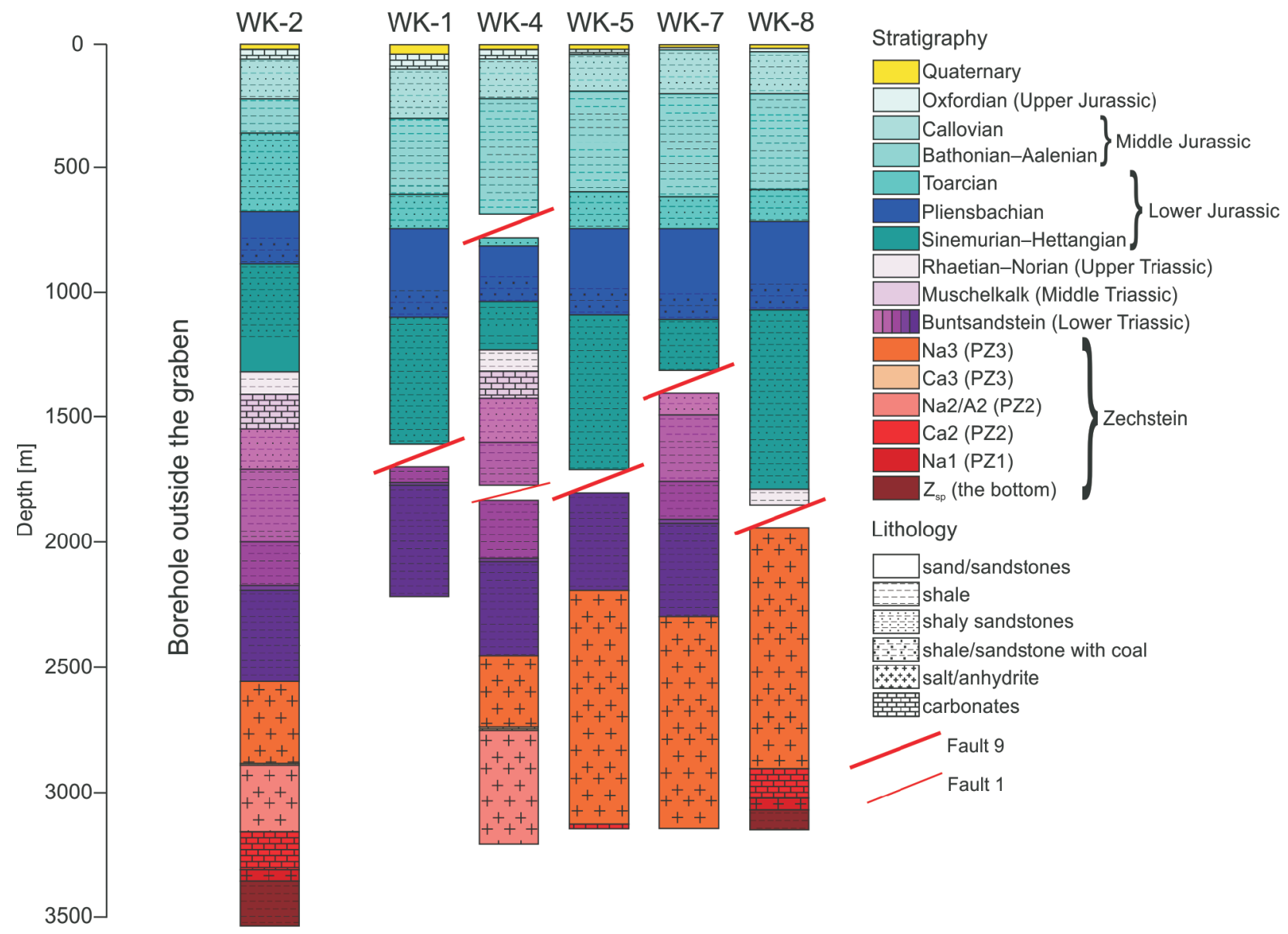

Fig. 3. Simplified lithostratigraphic profiles of the boreholes investigated

Note the gap in profiles caused by normal faults (marked by red lines); for borehole locations see Figure 2

WKG together with similar adjacent grabens is arranged in a horse-tail structural pattern, which is typical of strike-slip accommodation at the tip of a major fault zone (Kim et al., 2004; Kim and Sanderson, 2006). Its name comes from the characteristic arched shape of grabens and their serial appearance. The grabens are distributed along a presumed WNW-ESE trending basement fault zone, located within the SW marginal zone of the East European Craton (fault zone E of Krzywiec, 2006a). Zone of this basement fault has also been referred to as the SW boundary of the Czaplinek Block in the sub-Zechstein basement or extent of the Mid-Polish Swell in the Mesozoic succession (Pożaryski and Dadlez, 1987). In this study we have named this zone the Wolin-Drawsko fault zone.

The Szamotuły-Człopa tectonic zone adjoins the Wolin-Drawsko fault zone obliquely (Fig. 1B). Along this zone, salt diapirs rose in the Late Triassic-Early Jurassic, forming an en-echelon array (Dadlez and Marek, 1997). Also, farther to the SE, between Poznań and Kalisz, similar en-echelon half grabens, arranged in a linear pattern, were initiated in the Triassic and inverted in the Late Cretaceous (Kwolek, 2000). The patterns of grabens and diapirs and their synchronous origin suggest they both resulted from dextral transtension at the fault zones in the pre-Permian basement. Such specific serial structures oblique to the basement fault zone suggest decoupling between the Paleozoic and Mesozoic successions, preferentially within ductile Zechstein salts. The age of formation of the WKG is indicated by increased thicknesses of the upper Trias- sic and Lower Jurassic strata within the graben relative to the regional thickness (Figs. 4 and 5). However, the boreholes, located close to the eastern margin of the WKG, do not provide a complete section across the graben infill (Fig. 3) as they were drilled through the boundary fault and went into the footwall close to the base of Jurassic. Only the WK-8 borehole provides the complete Jurassic to top Triassic profile of the WKG (see Fig. 2) and the WK-2 borehole provides the entire Mesozoic profile outside the graben. Hence, there is no borehole control on the Middle and Lower Triassic deposits within the graben, the thickness of which was inferred from seismic interpretation, aided by data from outside the graben.

The WK-8 and WK-2 boreholes, located inside and outside the graben respectively, allow comparison of the changes in thickness of the Jurassic strata (Fig. 4), being $505 \mathrm{~m}$ greater within the WKG than outside it. This difference is mostly in the Hettangian-Pliensbachian sequence (400 m difference), while the rest (105 $\mathrm{m}$ difference) is attributed to the Toarcian-Callovian. However, the variations in Toarcian thickness alone, documented by boreholes, are compromised by a lack of good stratigraphic control, this being based on the geophysical logs without any palaeontological control.

The structural map and seismic horizon (Figs. 2 and 5) show that the graben is asymmetrical. The maximum throw of the eastern boundary fault (FTL9), measured at the top Muschelkalk seismic horizon $\left(T_{m}\right)$, is $>750 \mathrm{~m}$ and locally exceeds $900 \mathrm{~m}$ (Fig. 5B), while the throw at the western boundary 


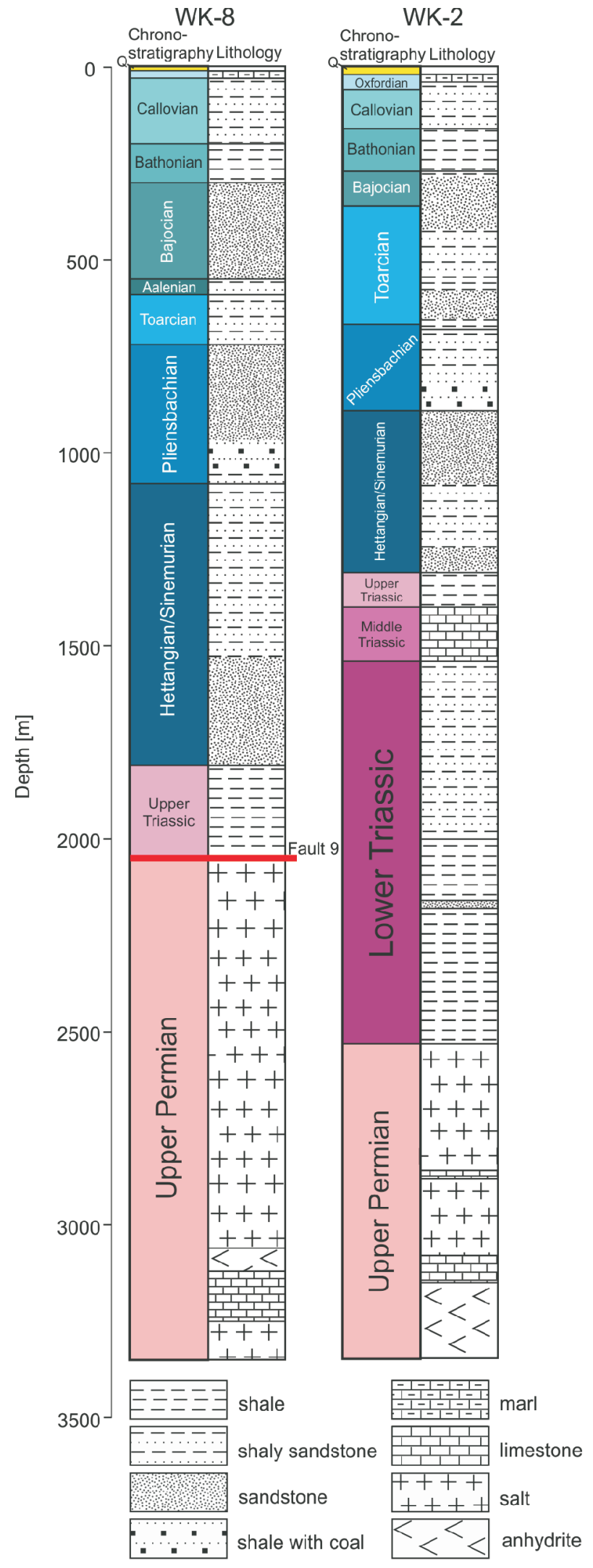

Fig. 4. A comparison of stratigraphic and lithological profiles of the boreholes WK-8 located within the WKG and WK-2 located outside the graben

Reduction in the WK-8 profile due to the FLT9 fault is marked by a red line. The significant increase in the thickness of the Jurassic strata inside the graben is clearly visible. The stratigraphic units shown have been mapped onto fault planes (Fig. 13). For borehole locations see Figure 2 fault (FLT8) varies in a range of $150-400 \mathrm{~m}$. The throw measured at the bottom Pleinsbachian seismic horizon $\left(\mathrm{J}_{\mathrm{p}}\right)$, changes between 300-460 m for the FLT9 fault, and 50-70 m for the FLT8 fault. The negative value is for an inverted fault with hanging wall higher than footwall. The difference between the throws of the $T_{m}$ and $J_{p}$ horizons indicates that the WKG was being infilled with sediments during graben formation. The thickness difference inside and outside the graben suggests that the main phase of graben formation lasted at least to the end of the Early Jurassic; however, the thickness increase in the Toarcian is subtle. The offset of the top Toarcian is very small across FLT8 and reaches several tens of metres across FLT9. Neither the quality of seismic profile of the middle Jurassic sequence nor the borehole data distribution allow for more detailed interpretation of the younger evolution of the WKG.

\section{COMPENSATION AND DECOUPLING OF DEFORMATION} IN THE ZECHSTEIN SALT LAYERS

The mechanism of FLT9 fault compensation within the Zechstein succession can be directly inferred from the seismic record (Fig. 5). This fault enters the Zechstein salts of the 2 nd and 3rd cycle without breaking the Main Dolomite and Basal Anhydrite $\left(Z_{1}-Z_{2}\right)$. The main boundary fault of the WKG is entirely compensated within the salt level.

Outside the WKG, the bottom of the Mesozoic succession is clearly lower on the western side of the graben with respect to the eastern side by $\sim 400 \mathrm{~m}$, while the base of the Zechstein is lacking a significant vertical offset (Fig. 5). This indicates that the faults bounding the WKG are entirely compensated within the Zechstein evaporites. A closer look at the Zechstein succession reveals that fault displacement is accommodated mostly by thicker salt layers ( $\mathrm{Na} 2$ and $\mathrm{Na} 3$ ). Compensation of faults bounding the WKG in the Zechstein succession is accompanied by salt thickness reduction in the western side of the WKG. Over this salt depression, outside the graben, the thickness of the Lower Jurassic sequence (Hettangian to Pliensbachian) increases, implying salt thickness reduction simultaneously with the graben subsidence. From this, it is clear that Zechstein thickness reduction is not a halokinetic phenomenon but developed due to salt stretching by simple shear at a compensated normal fault. Grabens developed by thin-skinned extension or listric normal faults often cause thickness reduction or even decay next to the graben (Fort et al., 2004; Jackson and Hudec, 2017). This phenomenon is similar to the reduction of a stratigraphic profile by normal faulting, with the difference that a normal fault is almost horizontal and the salt is deformed by creep in simple shear conditions.

On the eastern side of the graben, the rise of salt caused an almost co-shaped uplift of the Mesozoic succession above, without visible thickness changes in the Triassic and Jurassic units. However, a gradual decrease in stratal dip from the Lower Triassic to Jurassic can be noticed. This suggests the initiation of the salt pillow during inception of the graben and its final rise after the Early Jurassic. The lack of continuous reflections in the Middle Jurassic sequence makes it impossible to precisely constrain the timing of this event. Similar structures, called rollers, are described from an extensional tectonic environment compensated in salt on the Angolan passive margin (Fort et al., 2004). The rollers rise until the salt is wedged out beneath the graben, which, in our interpretation, also took place in the WKG.

\section{EXTENSIONAL AND STRIKE-SLIP COMPONENT} OF FAULT DISPLACEMENTS

The base Zechstein horizon is cut by many minor faults with throws less than $30 \mathrm{~m}$, which partially penetrate towards the Main Dolomite. To check the possible genetic relationship be- 
A

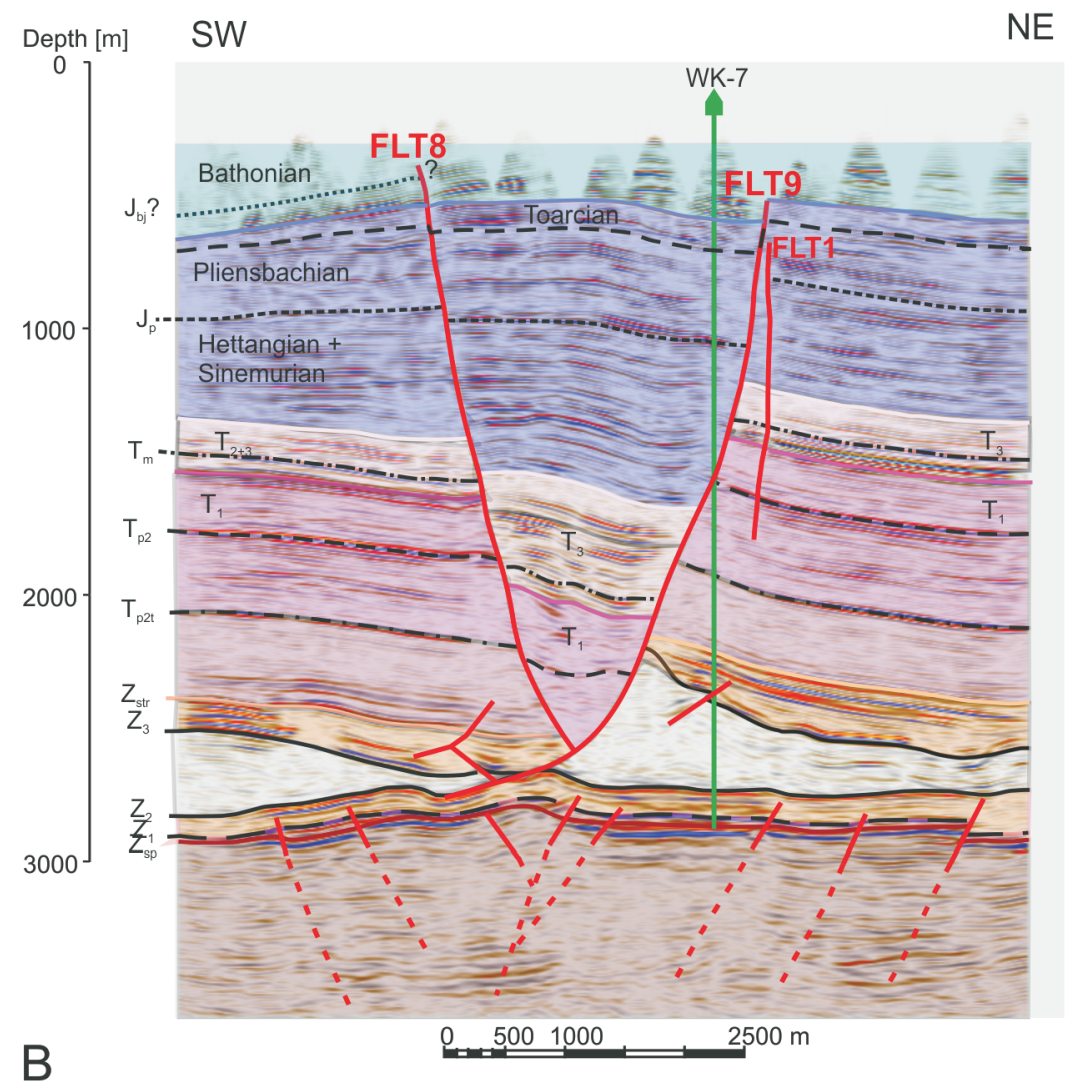

B

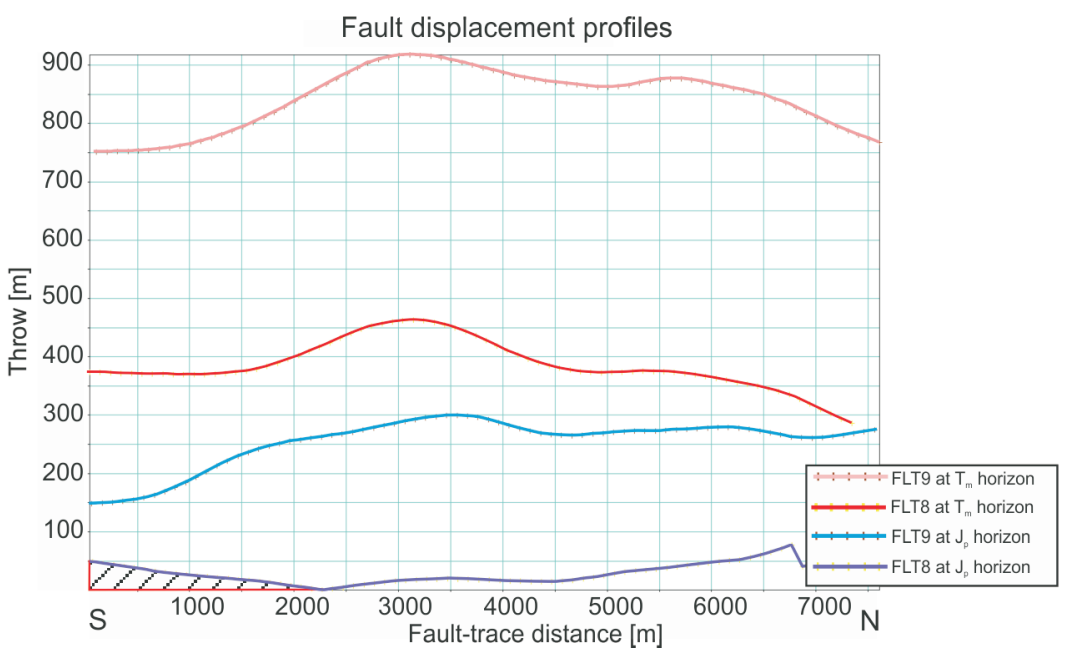

Fig. 5A - an example of a seismic section (location marked in Fig. 2) provides an interpretation of the main faults and seismic horizons supplemented by the stratigraphic units identified using borehole data. Due to seismic reflectors vanishing upwards, the shape of the top Bajocian horizon is hypothetical. Notice doubled vertical exaggeration of this profile. Hypothetical prolongation of faults below the Zechstein basement, forming a flower structure, is marked by a dashed line; B - a diagram of finite throw along strike of the two boundary faults FTL8 and FTL9. For each fault, two curves are drawn for the $T_{m}$ and $J_{p l}$ seismic horizons. Notice the reverse throw in the southern segment (hatched area) which, according to our interpretation, is a product of normal fault inversion tween the basement faults and the WKG, we have compared the strike of faults at both structural levels, based on a 3D seismic model (Fig. 7). The length of faults has been used for weighting the orientation of faults on the rose diagrams (Fig. 6). The diagram for the Paleozoic basement shows that faults create one orientation set, trending NW-SE with the maximum at azimuth $136^{\circ}$. Simultaneously, within the Mesozoic succession, faults trend NNW-SSE, with a mean azimuth of $154^{\circ}$. This difference is interpreted to be a result of strain decoupling in Zechstein salt between the dextral strike-slip fault zone in the basement, which caused transtensional tear-out of the Mesozoic sedimentary cover above. The deep and old basement faults were simply reactivated under oblique maximum horizontal stress. While there were no inherited fractures in the Mesozoic sequence it was torn out by motion of the basement fault. Structural discontinuity between both successions was possible due to decoupling in ductile salt layers. This mechanism might have produced the horse-tail pattern of the grabens. Following this concept, we expect that the boundary faults of the WKG, except for the dip-slip component, also has an additional strike-slip component of offset. In the case of flat-lying strata, the strike-slip component does not produce an apparent vertical offset and may insignificantly contribute to the fault throw.

Therefore, we infer that, in Figure 5 the fault throw represents only the extensional component of displacement, and so the strike-slip component is missing so far. This horizontal component of displacement cannot be determined directly from the data we have. However, assuming displacement between two marginal footwall blocks of the WKG in the direction of the basement fault, we are able to roughly predict the distribution of extensional and strike-slip components along the curved horse-tail graben (Fig. 6C). The extensional component of displacement can be measured in cross-section perpendicular to the trend of the graben (Fig. 5A). The strike-slip component is tangential to the graben trend. In a given curved graben geometry, this component decreases with increasing distance from the pure strike-slip basement fault. In the southern segment of the WKG analysed, we expect the strike-slip component to be comparable to the extensional one.

Based on the sum of the gaps between the hanging wall and footwall cutoffs in map view at the two boundary faults, the horizon- 
tal extension could be estimated across the graben. On the profile analysed (Fig. 5A) the total graben horizontal extension, measured at the $T_{m}$ seismic horizon, is estimated at $800 \mathrm{~m}$. Most of the extension seems to be related to the Lower Jurassic interval, as the horizontal gap at the bottom of the Jurassic sequence is estimated at $500 \mathrm{~m}$. The range of horizontal extension is similar to the sum of the vertical throw of the boundary faults due to their dip angle close to $45^{\circ}$ on average. Such low-angle normal faults are typical of faults propagating in poorly lithified deposits (McClay et al., 1991; Mauduit and Brun, 1998), as is the case of the syndepositional WKG origin. These faults tend to steepen upwards and flatten downwards within the Zechstein salts.

\section{YOUNGER PHASE OF WKG REACTIVATION}

Limited seismic data from the shallower $600 \mathrm{~m}$ makes it difficult to reconstruct the evolution of the graben after the stage of tectonically driven subsidence in the T3-J1 period. In our interpretation, the highest observable top Toarcian seismic horizon (the top Bajocian horizon is hypothetical) is also thrown by $\sim 100 \mathrm{~m}$ at the FLT9 boundary fault. It can be hypothesized that this minor offset was driven by differential compaction between the thicker soft sediments within the graben and the thinner ones outside. This effect should be accommodated in the Middle Jurassic sequence. However, younger fault reactivation also cannot be ruled out.

At the western flank of the WKG, the gentle tilt of the middle Jurassic seismic reflections is almost co-shaped with the bottom of the Zechstein succession. The regional context of the graben, also visible on the geological map without Cenozoic (Fig. 1B), indicates that the final inclination of the western flank of the graben took place during the uplift of the Mid-Polish Swell. The seismic image analysed is located on the SW slope of this swell. The time of the inversion, although impossible to specify from our data without the Cretaceous sequence, is clearly dated in other places to the Late Cretaceous (Dadlez, 1989; Krzywiec, 2006b). Judging from the reverse fault kinematics of the southern FLT8 fault segment at the $J_{p}$ horizon level (Fig. 5B), during this phase of compression the boundary faults were reactivated with reverse sense. Due to the curvature of the WKG, its southernmost NNW-SSE trending segment was preferentially oriented for transpressive reactivation when the SSW compression is inferred from the buckling faulting of the Mesozoic succession over Zechstein salts within the Szczecin Trough (Dadlez et al., 2000). The southern segment of the graben, which has the minimum extensional component and best orientation to reactivation, shows the maximum reverse offset at FLT8 in a range of $50 \mathrm{~m}$. The vertical component of inversion must have been higher than $50 \mathrm{~m}$, to compensate also for the previous normal faulting throw.

The SSW stress orientation with respect to the trend of the graben is in favour of transpressive reactivation of the southern segment of the WKG. As noted above, the salt pillow in the eastern flank of the WKG could have been finally uplifted by the buckling of the Mesozoic succession under the same compressional conditions as for basin inversion. In such conditions, minor normal fault reactivation of the FLT9 northern segment due to graben curvature is possible, but not proven.

\section{DIGITAL MODEL OF THE FAULT PLANES}

The tectonic interpretation of the seismic model allowed us to distinguish 11 faults (Fig. 7) within the Mesozoic succession, and 29 minor normal faults, and 2 thrust faults in the Zechstein succession, mostly interpreted at the Main Dolomite seismic horizon (Z1). The building of a spatial model of fault surfaces is a precondition for fault sealing potential analysis. Due to a perfect seal in salt, the faults in the Zechstein are not included in further sealing potential analysis. The fault models are computed using the commercial T7 software (http://www.badleys.co.uk/T7-SEAL.php). Within the software used, the fault attributes are calculated through a regular grid. In the study conducted, we have checked the influence of the grid size on results of fault computation using two conventional options of grid sizes, $100 \times 100$ and $50 \times 50 \mathrm{~m}$, for both faults and horizons. Since the results do not show significant differences, there is no need to increase model resolution above the standard $50 \times 50$, to avoid unnecessary computational cost (Caumon et al., 2009).

The fault throw, defined by the vertical component of the offset, is a variable depending on the location of the horizon intersection lines at the fault surface. To handle these variations, two cutoff lines for each horizon recognized are drawn on the fault plane, separately for hanging wall and footwall blocks (Fig. 8A). The vertical component of the distance between these two lines defines the fault polygon (Needham et al., 1996) that characterizes throw changes along fault strike, at the level of the given horizon (Fig. 8B). For each correlated stratigraphic horizon, fault polygons are computed automatically from the 3D model. To draw a throw map at the fault surface, the throw changes from all fault polygons are combined and recalculated on the model grid.

Considering the accumulation of errors in the multi-step model building procedure, the resultant fault throw maps have to be inspected. It is assumed that the ideal fault surface, approximated from the offset in one seismic event, has an elliptical shape with a regular throw pattern with a maximum near its centre and throw decrease towards the edge of the fault plane (Fig. 8B; Watterson, 1986; Walsh and Watterson, 1988; Needham et al., 1996; Kim and Sanderson, 2006). Such an idealized pattern is unrealistic for real fault geometry due to the accumulation of multiple slip on individual fault in a mechanically heterogeneous environment, and geodynamically changing conditions. Abrupt spikes, jumps, loops, or other irregularities are possible. In our interpretation, we assume a large margin of tolerance for irregular fault throw patterns, but if the throw map reveals short wavelength irregularities, not related to any interpreted fault segmentation, it is regarded as an artefact (Fig. 9). The correction of the artefact is made by the manual shift of nodes of the fault polygons until more gradual throw changes are achieved while keeping the initial range of the fault throw.

Our fault seal potential study is focused on the two largest faults, bounding the WKG from the west (FLT8) and east (FLT9), which control where the reservoirs within the graben are confined laterally. To construct a realistic fault model, the throw at the fault edges has to be defined. As the boundary faults were active in the Late Triassic-Early Jurassic interval of rapid sedimentation, their maximum throw is detectable in the Mid-Triassic $\left(T_{m}\right)$ fault polygon. The offset at the main FLT9 fault is accommodated downwards, within the Zechstein salts, 
A

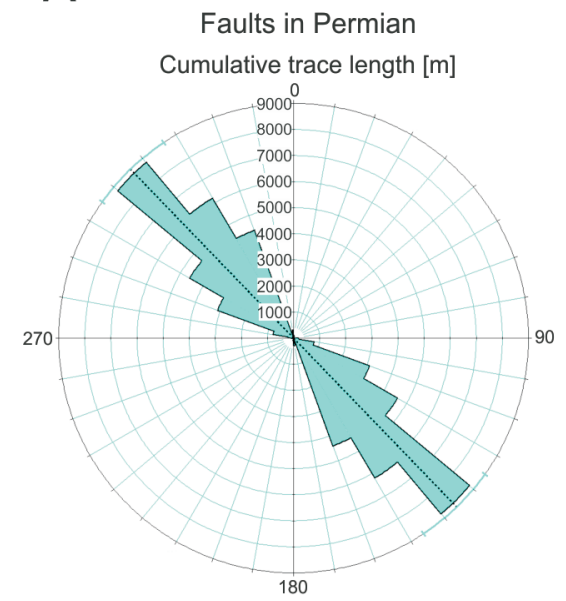

B

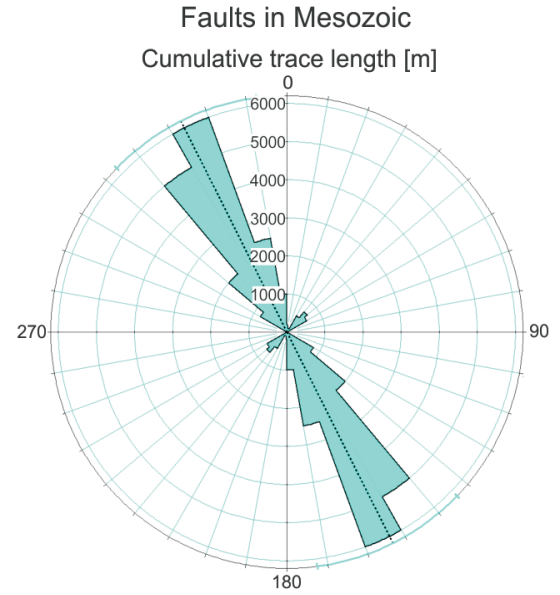

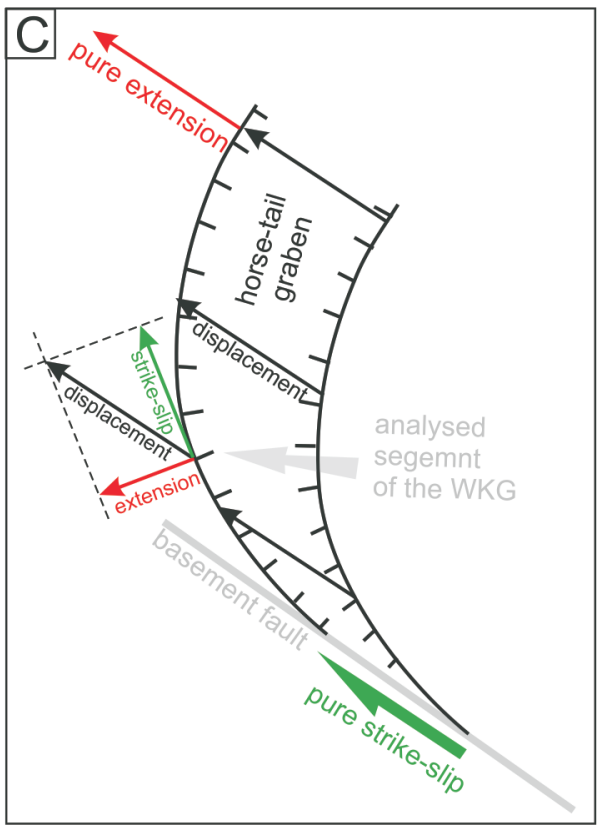

Fig. 6. Diagrams of fault strikes at two structural levels

A - for faults passing through the Zechstein basement; B - for faults restricted to the Mesozoic succession, the diagrams are weighted by the length of the fault lines measured at the base of the Zechstein $(A)$ and the lower $\mathrm{J}_{\mathrm{pl}}$ seismic horizon (B); $\mathrm{C}$ - the distribution of extensional and strike-slip components of horizontal displacement in the horse-tail graben, the strike-slip component is marked by green arrows, the extensional component by red arrows
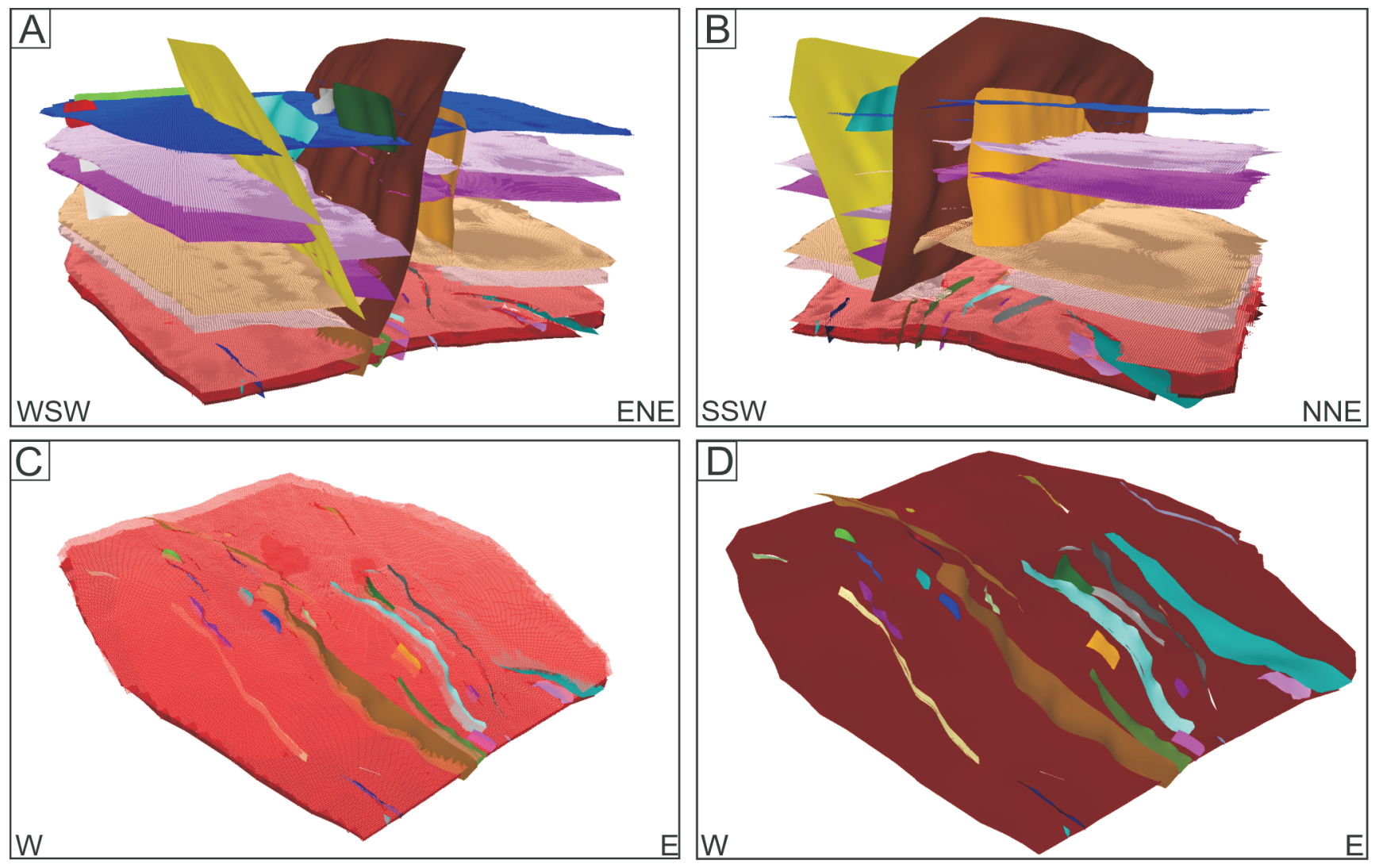

Fig. 7. An interpreted fault system

A - larger faults interpreted within the Mesozoic succession (dark blue horizon - lower Pliensbachian, light violet - Muschelkalk, dark violet middle Buntsandstein, pale orange - Zechstein top), where two main faults create the NNW-SSE striking WKG (A and B), more faults were interpreted in the Zechstein succession: Z2 horizon (C) and the $Z_{\text {sp }}$ horizon representing the base of the Zechstein (D), though their height and throw are limited 
A

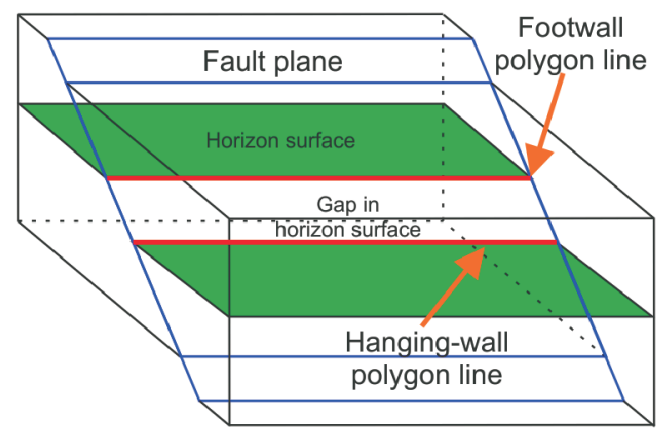

B

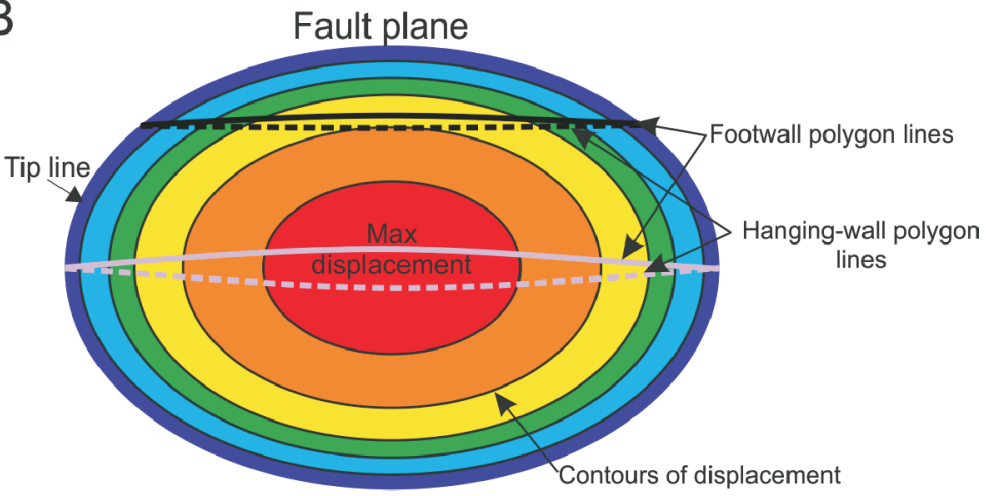

Fig. 8A - schematic presentation of a fault in the geological model, a fault plane within the horizon surface is represented by a gap limited by the hanging-wall and footwall polygons; B - an idealized elliptical fault plane with displacement values, the footwall and hanging-wall polygons are marked with solid and dashed lines respectively

where its throw drops to zero. The FLT8 terminates at FLT9, and its throw at the lower edge is still in the range of $400 \mathrm{~m}$. Upwards, both faults are compensated by a successive increase in sediment thickness within the WKG. Although it is not sure if the throw of both faults is entirely compensated by sedimentation, we assume zero throws at the bottom of the Quaternary.

\section{METHODS OF FAULT SEALING POTENTIAL MODELLING}

Considering the data limitation, our fault sealing potential study is simplified to a high-level analysis, which can be helpful in storage site localization, but certainly does not meet the standards for storage site characterization (Celia et al., 2015). Our analysis is conducted based on the assumption that the fault sealing potential is determined by two components: (1) the sealing properties of the strata juxtaposed on both sides of the fault (juxtaposition component of seal) and (2) the sealing properties of the fault zone itself (fault gouge component of seal). The analysis follows the recommendations of the T7 software provider and the practice of the oil industry (Fristad et al., 1997; Bretan, 2017).

\section{JUXTAPOSITION COMPONENT OF FAULT SEALING POTENTIAL}

The juxtaposition type of seal enables an indication of the possible communication pathways between reservoirs in different tectonic blocks on opposite sides of the fault plane. To achieve this, the permeable (sandstone) and sealing (shale) rock series need to be identified. Where analyses are dedicated to permeable reservoirs, the kinds of rock juxtaposed against reservoir units on the other side of the fault plane need to be assessed (Yielding et al., 2010). The seal can be characterized either quantitatively using e.g. permeability determined from the borehole logs and calibrated by laboratory testing of rock samples, or qualitatively by using lithological divisions. Having the 3D model of fault throw, the juxtaposition plots can be constructed using a modified Allan diagram (Allan, 1989; Knipe, 1997). The maps of fault throw are used to calculate maps of lithological couples across the fault planes, representing footwall and hanging-wall blocks (Fig. 10). For each couple of the juxtaposed lithological units, a separate division is attributed, e.g.: sand/sand, shale/sand, sand/shale, or shale/shale.
The order of lithological units in couples depends on the interpreter's arbitrary judgment.

FAULT GOUGE COMPONENT OF FAULT SEALING POTENTIAL

To estimate the gouge component of fault sealing potential, several algorithms are available based on host-rock lithology and fault throw. Parameters such as Clay Smear Potential (Bouvier et al., 1989; Fig. 11A) and Shale Smear Factor (Lindsay et al., 1993; Fig. 11B) are built on the assumption that the likelihood of clay smearing in fault segments with juxtaposed sand/sand lithology is related to the combined thickness of shale beds and fault throw. However, in some reservoirs, especially those containing highly heterogeneous sequences, it is not feasible to distinguish and map each shale bed. Because the WKG field also represents such a case, we use the equation proposed by Yielding et al. (1997) and calculate the Shale Gouge Ratio (SGR), which is the percentage share of shale in the throw interval (Fig. 11C). When the clay minerals cannot be assessed from the data, for practical reasons the clay mineral contents are conventionally described by the $\mathrm{V}$-shale $\left(V_{s h}\right)$ parameter, which stands for the volumetric share of shale material (Bretan et al., 2003; Corona et al., 2010; Vrolijk et al., 2016). The $V_{\text {sh }}$ parameter can be interpreted from gamma-ray logs according to the method described by Asquith and Krygowski (2004), which proposes a linear dependence of gamma-ray in$\operatorname{dex}\left(I_{G R}\right)$ on gamma-ray values (Eq. 1):

$$
V_{s h}=I_{G R}=\frac{G R_{\log }-G R_{\min }}{G R_{\max }-G R_{\min }}
$$

where: $I_{G R}$ - gamma-ray index, $G R_{\text {log }}$ - gamma-ray log reading, $G R_{\min }$ - gamma-ray log reading in clay-free zone, $G R_{\max }$ gamma-ray log reading in pure-clay zone

Besides this linear equation, there are also some nonlinear empirical solutions for given sedimentary basins or formations, as proposed by Stieber (1970) and Clavier et al. (1971). However, having no "ground truth" dataset for the gamma-ray log calibration, we have to apply the simplest linear approach. The $V_{\text {sh }}$ profiles derived from the gamma-ray logs are distributed across the 3D model using geostatistical methods, separately for hanging-wall and footwall blocks of the fault analysed. 

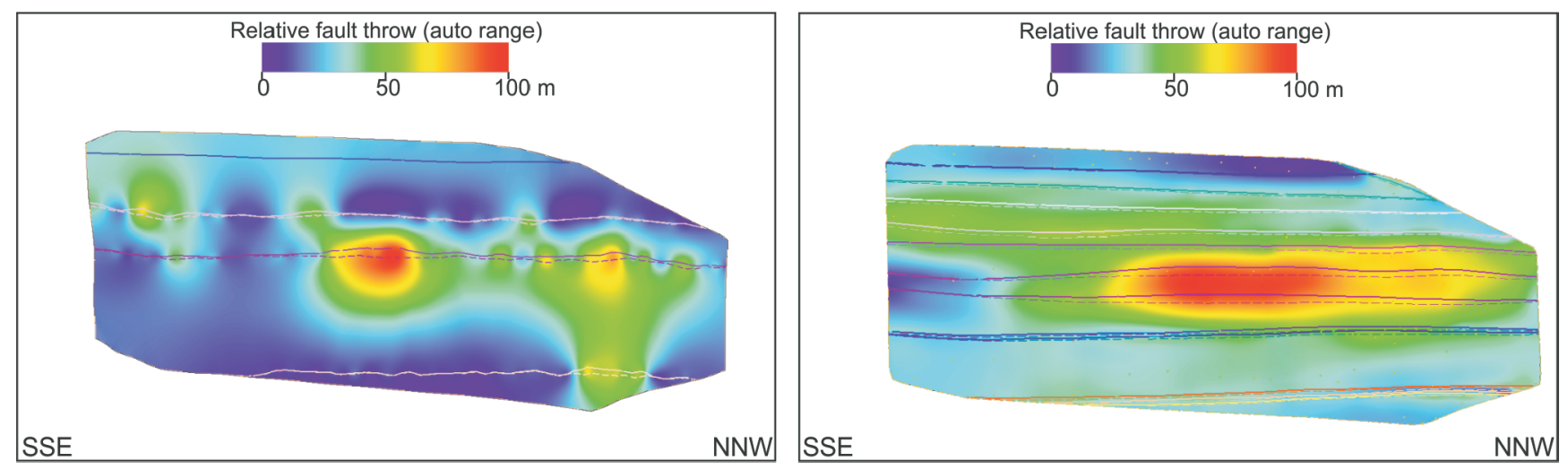

Fig. 9. An example: the FLT1 fault with mapped throw values before correction (left) and after correction (right)

For location see Figure 2

Having the shale distribution on the 3D grid and a throw map at the fault planes defined we are able to calculate the Shale Gouge Ratio parameter for each grid element of the fault plane using the following equation (Yielding et al., 1997; Eq. 2):

$S G R=\frac{[(\text { Zone thickness }) \times(\text { Zone shale fraction })]}{\text { Fault throw }} \times 100 \%$

Generally, the SGR parameter represents the ratio of shale material that might be entrained in the fault zone, assuming the rocks of fault walls are, on average, evenly mixed. Thus, the bulk composition of the hanging wall and footwall rocks is computed.

The SGR parameter does not directly indicate whether the fault is sealing or not. To obtain useful results, this parameter should be calibrated. For instance, observations made in the Columbus Basin and Brent province (Yielding et al., 2010) imply that a SGR of $<20 \%$ is characteristic of non-sealing disaggregation-zones, while values growing in a range of $20 \%<$ $S G R<50 \%$ indicate successively growing fault sealing potential (Yielding et al., 2010). A SGR of $>50 \%$ points to a perfect seal. The interpretation of intermediate values of $S G R$ is somewhat arbitrary if detailed gouge studies are not performed. According to Yielding et al. (2010), moderate values of SGR imply that the fault zone is composed of phyllosilicate-framework rocks and the sealing potential is controlled by the development of networks of micro-smears around the grains of the fault rocks. Thus, they behave in the same way as a typical clay smear even when the shale beds involved in fault movement are thin (Knipe, 1992; Knipe et al., 1997).

\section{FAULT SEALING POTENTIAL WITHIN THE WKG}

\author{
RESERVOIRS AND SEALS WITHIN THE WKG
}

Definition of reservoir and seal successions is a prerequisite of fault seal potential analysis. To define the reservoirs and caprocks and evaluate the fault gouge seal component, the distribution of the $\mathrm{V}$-shale parameter $\left(V_{s h}\right)$ has been computed for five boreholes: WK-1, WK-4, WK-5, WK-7, and WK-8 (examples in Fig. 12A), for which gamma-ray logs and geological documentation including stratigraphic profiles were available. Simplified lithological divisions have been attributed to consistent $\mathrm{V}_{\mathrm{sh}}$ intervals based on integrated borehole documentation and interpretation supported by regional facies distribution patterns (http://otworywiertnicze.pgi.gov.pl/; Figs. 4 and 12A). Having no core samples, we are not able to verify lithological divisions. Based on borehole interpretation, the $V_{s h}$ values are extrapolated across the WKG using T7 software (Fig. 12B).

The following ranges for $V_{s h}$ values are attributed to lithological divisions: $V_{s h}<20 \%$ are pure sandstones; $V_{s h}$ in the range of $20-30 \%$ are sandstones with mudstone interbeds; $V_{s h}$ in the range of $30-40 \%$ are heterolithic, with shale intercalations (interpreted as shaly sandstones); and $V_{s h}>40 \%$ are predominantly shales. In a further scheme, reservoirs are defined by $V_{s h}<30 \%$ and caprock by $V_{s h}>40 \%$. $V_{s h}$ values between

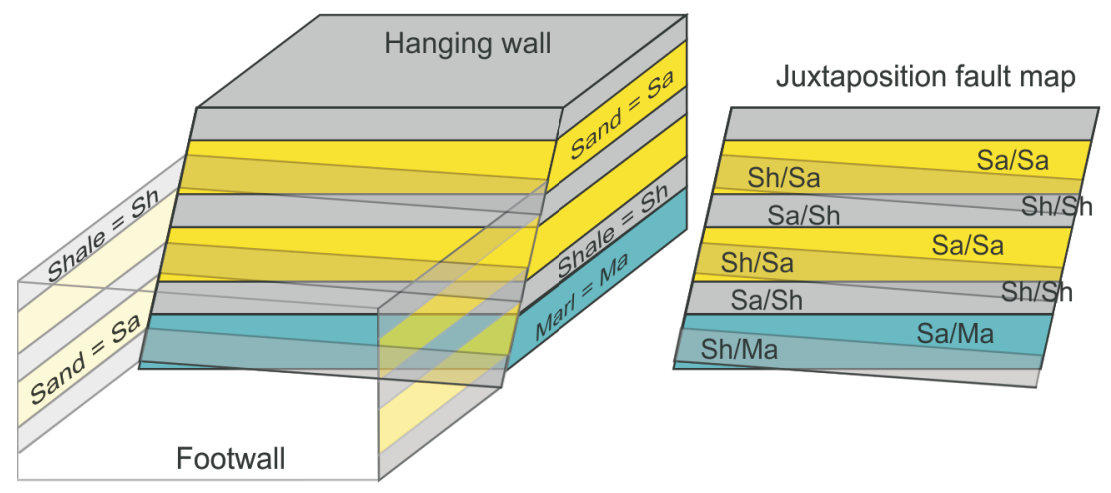

Fig. 10. The concept of Allan diagram construction in a 3D geological model (Allan, 1989) and a final juxtaposition map at a fault surface with lithological couples marked 


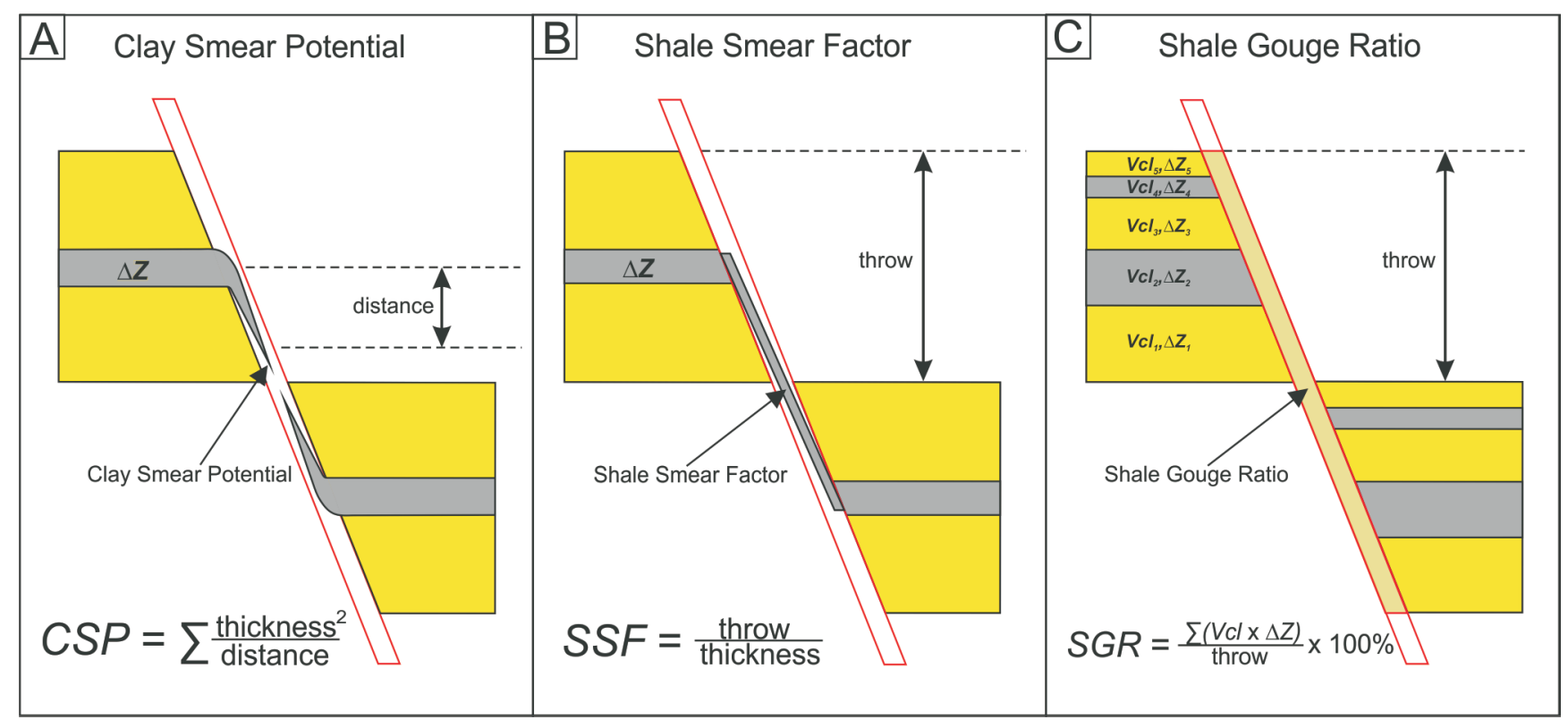

Fig. 11. A set of main fault seal algorithms (after Yielding et al., 1997)

See text for explanation

$30-40 \%$ are transitional between the previously noted values (Fig. 12B). To allow correlation of reservoirs and seals across the model we block the borehole sections with highly variable $V_{\text {sh }}$ values in consistent units depending on the prevailing $V_{s h}$ values. This approach was applied to the clastic rocks while evaporites and carbonates were treated separately.

Using these criteria, we found that in the Triassic sequence there is only a 15-20 m thick sandstone in the Buntsandstein, which due to its small thickness cannot be considered an effective reservoir (Fig. 4). In the Mid-Triassic Muschelkalk, there is a carbonate sequence $>100 \mathrm{~m}$ thick, in which matrix porosity and permeability are highly variable judging from the regional dataset covering the Polish Basin (Gancarz, 2015; Sowiżdżał and Semyrka, 2016). Almost $50 \%$ of the samples reveal porosity of $<2 \%$, while the rest ranges up to $13 \%$ (neglecting some outliers), which results in permeability ranging from 0.1 to $100 \mathrm{mD}$. To define the role of the Muschelkalk play in the confinement analysis of the WKG, its properties need to be determined for this location. Tentatively, we attribute uncertainty to these carbonates. In the Upper Triassic section, there are no pure sandstone aquifers of significant thickness (see also Fig. 12).

The best potential reservoirs are found in the Jurassic sequence. The Hettangian and Sinemurian sections include at least two intervals predominantly of sandstone (WK-5, WK-2; Figs. 4 and 12). The best quality, lower reservoir near the bottom of the Hettangian is at least $200 \mathrm{~m}$ thick. It is separated by a heterolithic interval $>100 \mathrm{~m}$ thick with thin sandstone to mudstone intercalations from the upper reservoir at the top of Sinemurian, which is however neither pure sandstone nor laterally continuous. At the bottom of Pliensbachian, there is shale several tens of metres thick, with coals, which underlies Pliensbachian sandstones which are interbedded with shale. Despite its impurity, the entire Pliensbachian section dominated by sandstone, up to $300 \mathrm{~m}$ thick, is regarded as a reservoir. There are large lateral lithological changes in the Toarcian sec- tion, including intercalated sandstones, mudstones, and claystone, that transition upwards into a thin Aalenian shale. In the lower part of the Bajocian section, there are two sandstone reservoirs, $\sim 100$ and $50 \mathrm{~m}$ thick, which are separated by heterolithic deposits. We combine both into one reservoir unit, which is sealed at the top by shales almost $100 \mathrm{~m}$ thick, and by Bajocian to Bathonian heterolithic deposits with claystone at least $200 \mathrm{~m}$ thick. The Callovian sandstone section, >100 m thick, is overlain by thin Oxfordian marls and by Quaternary deposits. Lacking a sealing caprock, the upper sandstone is not considered a reservoir.

Generally, the Jurassic sequence within the WKG includes three continuous reservoirs separated by caprock sequences (Fig. 12): (1) a lower sandstone, Hettangian, reservoir, overlain by heterolithic deposits; (2) a heterogeneous Pliensbachian reservoir underlain by a sealing shale and overlain by a Toarcian-Aalenian, only partially sealing, sequence; (3) a Bajocian reservoir, which is overlain by thick BajocianBathonian sealing shales. The best sealing caprock seems to overlie the upper Bajocian reservoir.

\section{JUXTAPOSITION SEALING POTENTIAL OF THE WKG BOUNDARY FAULTS}

Assessment of the juxtaposition seal component is performed for the graben-bounding faults (FLT8 and FLT9, Fig. 13). We have adopted the maximum thicknesses of reservoirs to give a pessimistic solution for sealing potential. The limestone and sandstone layers in the Triassic of the WKG are generally well-sealed by shale outside the graben, with a minor exception in the lower Triassic, where a thin sandstone layer is juxtaposed to shaly sandstone at the FLT8 fault plane. The solution for the Jurassic reservoirs is more complex. At the FLT9 fault, the Hettangian reservoir is well sealed by Triassic shales. At the FLT8 fault, a large part of the Hettangian reservoir is jux- 

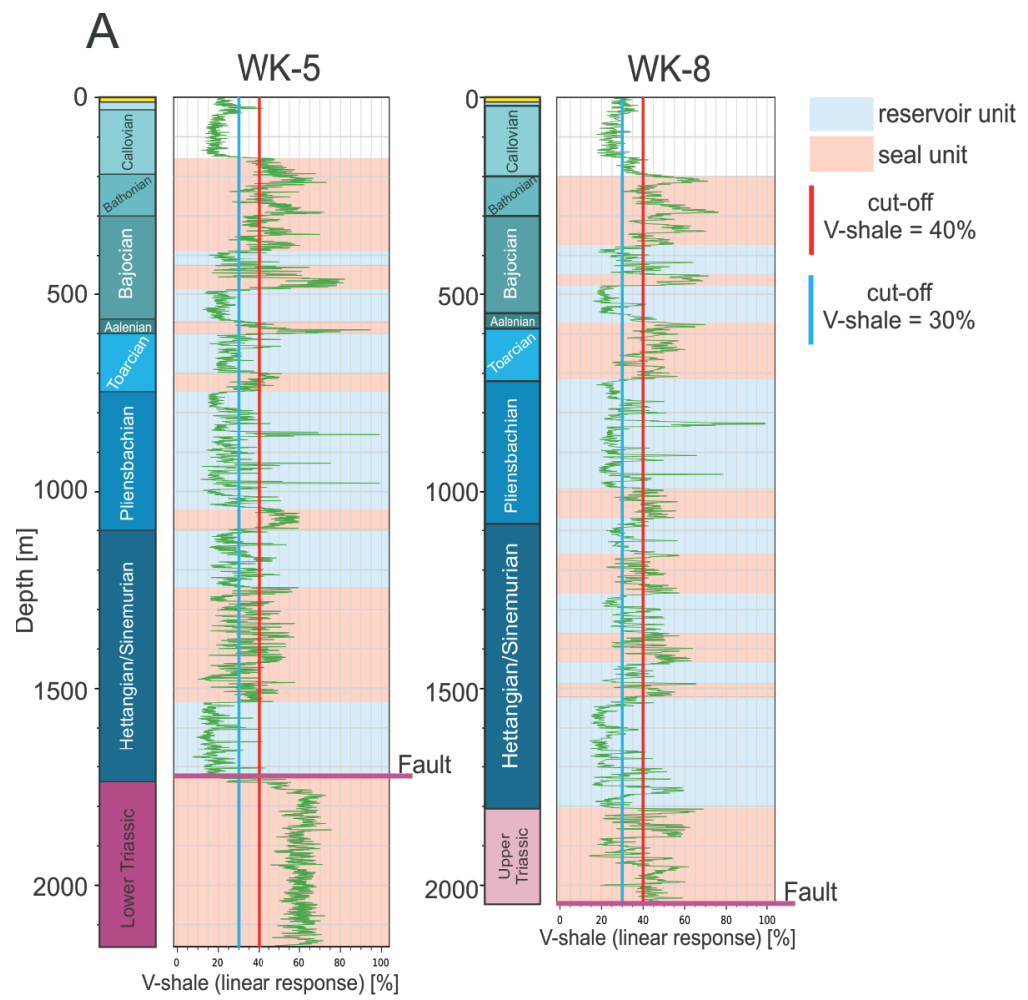

B

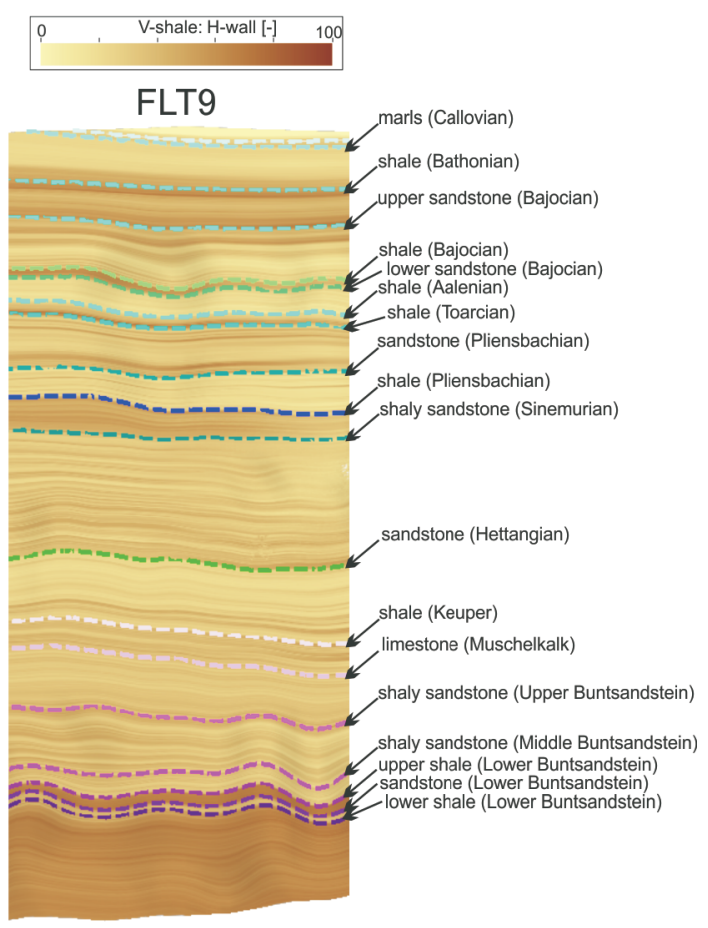

Fig. 12A - V-shale $\left(V_{s h}\right)$ profiles calculated using a linear equation for the WK-5 and WK-8 boreholes covering the Mesozoic interval (for location see Fig. 2), the formations showing $V_{s h}>40 \%$ are good caprocks (pink intervals, corresponding to shale layers), and the $V_{s h}<30 \%$ are reservoirs (blue areas, corresponding to sandstone layers), $V_{s h}$ values between 30 and $40 \%$ are interpreted as shaly sandstones; B - V-shale distribution in the hanging-wall block mapped at the segment of FLT9 fault surface close to the boreholes, calculated using T7 software, the tops of lithostratigraphic units are marked by arrows, and the reservoirs are indicated by numbers, referred to in the text

taposed against Muschelkalk limestone, the sealing properties of which are uncertain. The Pliensbachian reservoir is also better sealed at FLT9, where part of the reservoir is juxtaposed to shaly sandstone, which is assumed to have poor sealing property. At the FLT8 fault, due to an upward decrease in fault throw, the self-juxtaposition zone is observed within the thick Pliensbachian reservoir, which is not sealed from this side. Further decrease of both faults throws causes self-juxtaposition of the Bajocian reservoir from both sides of the graben. This reservoir, well-sealed at the top, is certainly unconfined laterally by the juxtaposition component on the boundary faults. In general, juxtaposition sealing for Jurassic reservoirs is uncertain or ineffective from the western side, at the FLT8 fault. On the eastern side of the graben, the sealing potential decreases systematically for shallower reservoirs, together with the decreasing throw of the FLT9 fault (Fig. 13).

\section{FAULT GOUGE SEALING POTENTIAL OF THE WKG MARGINAL FAULTS}

To compute the fault gouge sealing potential, the $\mathrm{V}$-shale profiles have been extrapolated to the 3D model (Fig. 12) and then mapped at the fault surface from both sides, the hanging-wall and footwall blocks. Having throw maps of the faults analysed, mean values of the shale fraction have been computed for each grid cell at the fault surfaces, using the T7 software. Following Yielding et al. (2010) we assume that SGR values correspond to fault sealing potential in such a way that $S G R$ $<30 \%$ ( $V_{\text {sh }}$ related to reservoirs) indicates a lack of seal, SGR between $30-40 \%$ ( $V_{s h}$ for heterolithic deposits) should be considered as a moderate seal, and the $S G R>40 \%$ is characteristic of good seal ( $V_{s h}$ for shale).
The Lower Triassic sequence has good gouge sealing potential from both sides (Fig. 14). The Muschelkalk sequence is well-sealed from the FLT9 side while from the FLT8 side the seal is moderate or even poor in the SSE segment of this fault (SGR <30\%). The Upper Triassic sequence is mostly well sealed from the FLT9 side and moderately sealed from the FLT8 side. For the Jurassic sequence, a more complex fault sealing pattern is inferred. The lower Hettangian reservoir has a moderate seal from both sides $(30 \%<S G R<40 \%)$, with a more certain one from the FLT9 side, where in some places SGR exceeds $40 \%$. A general decrease of gouge sealing potential of the Sinemurian sequence is visible in the NNW FLT8 fault segment ( $S G R<30 \%$ ). The Pliensbachian reservoir has a moderate seal from the FLT9 fault side with a small sandstone window (SGR <30\%). From the FLT8 side, the gouge sealing component is ineffective, as the majority of the reservoir has $S G R<30 \%$. The Bajocian reservoir, in general, is unsealed by fault gouge from both sides of the WKG, although there are some places in the NNW segment of FLT9 with SGR in the range of $20-40 \%$. In general, a tendency to decrease the fault gouge sealing potential upwards due to decreasing throw of both boundary faults in the same direction can be observed.

\section{CONFINEMENT OF THE JURASSIC RESERVOIRS WITHIN THE WKG}

In our analysis, the juxtaposition sealing component, which relies on a simple lithological description, has only qualitative meaning. The fault gauge component, although given in percent has a semi-quantitative value, based on the Vshale parameter, which is not strictly calibrated by clay mineral content or permeability. Therefore, a combination of these two compo- 

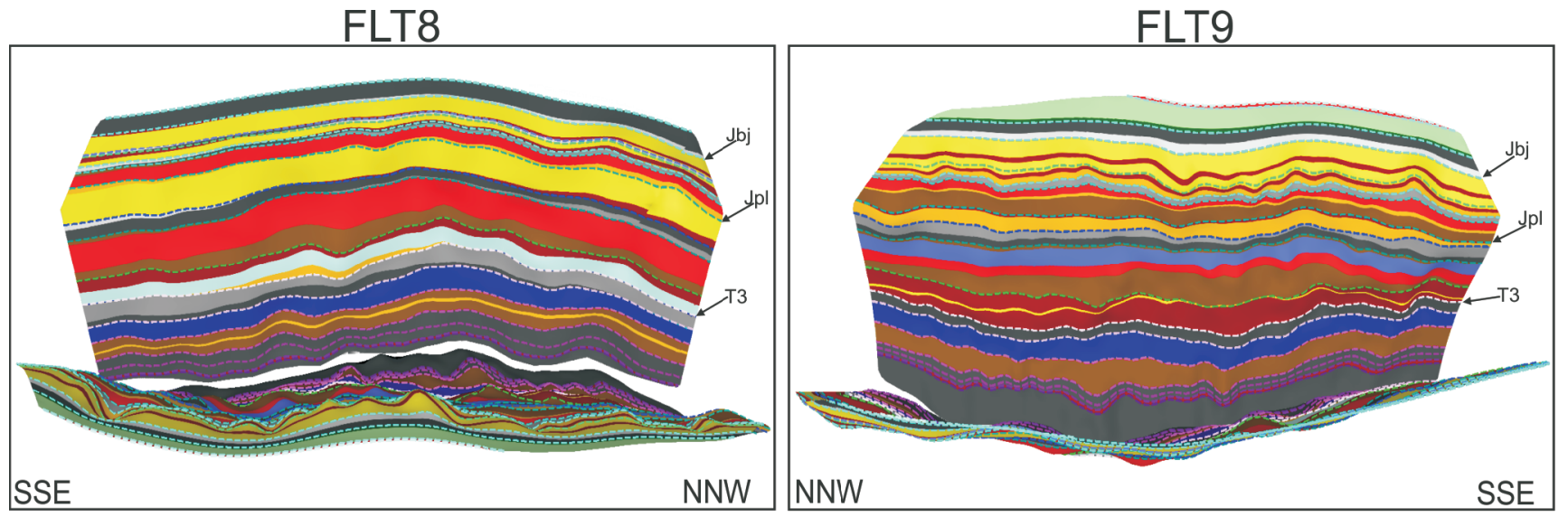

Juxtaposed lithotypes (hanging-wall/footwall)
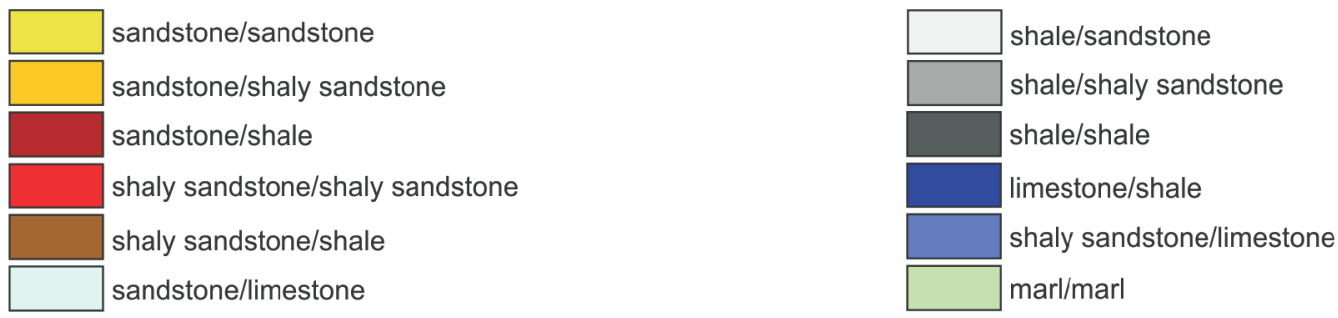

Fig. 13. The juxtaposition of lithotypes across the boundary fault surfaces

In the legend, the first lithotype is given for the hanging wall (inside the graben). The lithology shown at the fault surface is a footwall template while dashed lines represent the hanging wall template horizons, marked as $\mathrm{T}_{\mathrm{m}}$ - bottom of Hettangian reservoir, $\mathrm{J}_{\mathrm{pl}}-$ bottom of Pliensbachian reservoir; $\mathrm{J}_{\mathrm{bj}}$ - top of Bajocian reservoir. The views of fault geometry are from inside the graben

nents may have only a qualitative value. Summarising sealing components for the boundary faults (Table 1 ) we can conclude that the Triassic is well confined within the WKG, either by juxtaposition or gouge component. The Hettangian reservoir is well confined by juxtaposition seal from the FLT9 side. From the FLT8 side both sealing components are uncertain, due to the juxtaposition of Muschelkalk limestone and moderate gouge seal. The Pliensbachian reservoir has both sealing components uncertain from the FLT9 side and a lack of seal from the FLT8 side of graben. The Bajocian reservoir seems to be unconfined from both sides of the WKG.

From the above, it follows that the only reservoir that can be considered in a further storage scenario is the Hettangian reservoir. However, its sealing properties, especially from the western side of the graben, should be carefully tested. Except for lateral confinement, the depth of this reservoir below $1500 \mathrm{~m}$ provides good conditions for $\mathrm{CO}_{2}$ storage in a supercritical state, which is usually guaranteed at a depth exceeding $800 \mathrm{~m}$ (Wang et al., 2019). This reservoir has a significant thickness of $>200 \mathrm{~m}$ of pure sandstone which is one of the best in the Jurassic sequence within the WKG. Due to the clustering of the boreholes studied, lateral continuity of this reservoir is not documented, however, its regular appearance in borehole profiles and regional constraints (Dadlez et al., 2000), suggest its continuity within the graben and its surroundings. A direct caprock comprising a thick heterolithic section probably does not guarantee the permanent maintenance of injected fluid into this reservoir. However, seepage into the shallower reservoir seems to be unlikely due to the good quality seal at the bottom of the Pliensbachian reservoir. Therefore, we believe that this reservoir can be considered as an effective storage option for waste fluids, but due to the lack of direct good seal, not a good option for methane, which should be entirely extracted from the storage.

\section{DISCUSSION}

One of the most fundamental problems with fault seal analysis is fault zone complexity, which is often beyond data control. Faults usually have several secondary slip surfaces (Childs et al., 2009), meaning that juxtaposition analysis realized in several steps may result in a solution quite the opposite than that in a one-step throw, as is assumed in our study. Serial faults in one fault zone may form an unbreached relay (Manzocchi et al., 2008), creating continuous hydrodynamic windows across the fault zone. Another important issue related to the interpretation of juxtaposition plots is fault drag, which is usually insufficiently represented in a seismic record (Hesthammer and Fossen, 2000). The flexural bending of strata in the vicinity of a fault may change the effective discontinuous throw, which is a crucial parameter for a fault sealing potential analysis. Thus, we touch upon the important issue of the observation scale and the resolution of data. When the fault model relies on the seismic data, separation of discrete faults below seismic resolution is impossible. To reduce the risk of an over-simplified fault zone model, the seismic data should be supplemented with structural analysis of borehole data, among which borehole core profiling, micro-images, and dipmeter logs are most valuable. However, the fault gouge sealing component can be less dependent on scale of observation, as one large fault with a widely smeared fault gouge may have a similar effect as a large number of small faults with smeared fault gouges of smaller extent. 

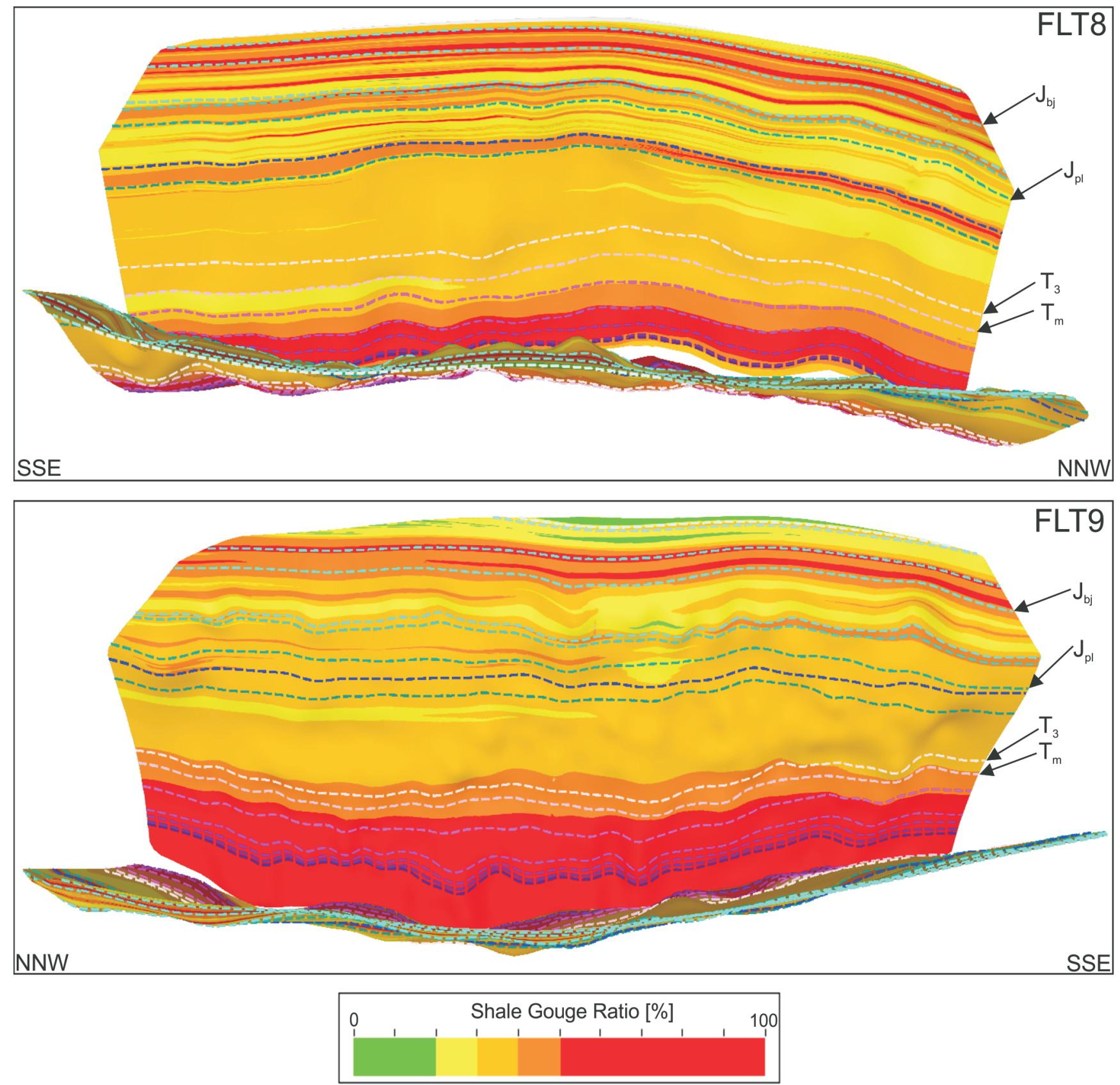

Fig. 14. Distribution of the $S G R$ parameter using the values of $V_{s h}$ calculated from the linear response for two marginal faults of the graben (see Fig. 7)

The higher percentage indicates higher clay mineral contents in the fault gouge and a better seal potential. The views of faults are from inside the graben. Hanging wall cutoff lines are shown: $T_{m}-$ bottom of Hettangian reservoir, $T_{3}-$ top of Triassic, $J_{p l}-$ bottom of Pliensbachian reservoir; $\mathrm{J}_{\mathrm{bj}}$ - top of Bajocian reservoir

Another problematic issue is related to fault development during sedimentation, which may cause lateral variability of the facies in the vicinity of an active fault. This might be a more important factor when we consider that the main Jurassic reservoirs accumulated in terrestrial and shallow coastal environments (Feldman-Olszewska, 1997), which favours high lateral facies variability and sensitivity to tectonic factors. The arrangement of boreholes in one cluster, as in our study, does not allow control of these changes across the WKG. This kind of risk factor is somehow reduced by the fact that the sealing shale horizons are laterally more homogeneous, especially in upper and middle Jurassic strata, when deep-water facies prevailed. More sophisticated data acquisition and processing focus on the interpretation of elastic properties that may express facies distribution (Kemper and Gunning, 2014; Pandey et al., 2020) and so may reduce this uncertainty.

Fault gouge sealing potential analysis in our study has not considered the thickness of the fault gouge, which may be related to the thickness of the fault core zone (Shipton et al., 2005; Torabi et al., 2019). This parameter, which is important but difficult to assess from geological data, contributes to effective fault gouge sealing potential. It can be assumed that at 
Generalised results of the fault sealing potential analysis for the graben-bounding faults at a level of assumed reservoirs within the WKG, the Muschelkalk level is included, although the existence of effective reservoir facies is uncertain

\begin{tabular}{|c|c|c|c|c|c|c|}
\hline \multirow[b]{2}{*}{$\begin{array}{l}\text { Stratigraphic } \\
\text { sequence }\end{array}$} & \multirow[b]{2}{*}{$\begin{array}{l}\text { Reservoir } \\
\text { unit }\end{array}$} & \multicolumn{2}{|c|}{ The main FLT9 fault } & \multicolumn{2}{|c|}{ The secondary FLT8 fault } & \multirow[t]{2}{*}{ Comment } \\
\hline & & Juxtaposition & $\begin{array}{c}\text { Fault Gouge } \\
\text { SGR [\%] }\end{array}$ & Juxtaposition & $\begin{array}{l}\text { Fault Gouge } \\
\text { SGR [\%] }\end{array}$ & \\
\hline Bajocian & Sandstone & $\begin{array}{c}\text { Sandstone } \\
\text { Shaly Sandsotne } \\
\text { Shale } \\
\end{array}$ & $20-30$ & $\begin{array}{l}\text { Sandstone } \\
\text { Shale }\end{array}$ & $20-30$ & Poorly constrained \\
\hline Pliensbachian & Sandstone & $\begin{array}{c}\text { Sandstone } \\
\text { Shale }\end{array}$ & $20-40$ & $\begin{array}{l}\text { Sandstone } \\
\text { Shale }\end{array}$ & $20-30$ & Poorly constrained \\
\hline $\begin{array}{l}\text { Sinemurian/ } \\
\text { Hettangian }\end{array}$ & Sandstone & $\begin{array}{c}\text { Shale } \\
\text { Shaly Sandstone }\end{array}$ & $30-40$ & $\begin{array}{c}\text { Limestone } \\
\text { Shale } \\
\text { Shaly Sandstone }\end{array}$ & $30-40$ & $\begin{array}{l}\text { Well constrained to } \\
\text { uncertain }\end{array}$ \\
\hline Muschelkalk & Limestone & Shale & $40 \rightarrow 50$ & Shale & $20->40$ & Well constrained \\
\hline
\end{tabular}

shallow depths, where shear stresses are low (Zoback, 2007), failure conditions may vary between brittle sandstones and ductile shales. Hence, an initial complex fault surface morphology may result in variability of the fault gouge zone thickness. This increases the probability of a local complete reduction of a fault gouge zone. Observations by Murray et al. (2019) on 42 hydrocarbon fields suggested that the hydrocarbon column was most closely predicted when a lack of gouge seal was assumed. We cannot exclude the existence of hydraulic windows lacking gouge in the WKG, however, this is not possible to be verified without analysis of pressure compartmentalization, which has not been done in the study area.

Considering the internal structure of fault zones, the dilation zone also needs to be mentioned (Zhang and Sanderson, 1996), as this may create a conductive network of open fissures. The propagation of such pathways across a caprock depends mostly on its brittleness. In our case, when reservoirs were faulted at shallow depths, ductile shale may be expected in the caprocks, and these are not susceptible to brittle failure. Considering that possible brittle failure may be healed by ductile creep in shale or mineral precipitation, we do not expect a significant contribution of this uncontrolled factor to the sealing potential of the faults studied.

Among inherent deficiencies of fault seal potential analysis, including our study, are fault inversion and a strike-slip component of displacement. Although both phenomena should increase fault gouge production, they are not included in seal potential analysis; instead, only the final throw in a dip-slip direction is considered. However, we believe that due to minor inversion of the WKG and also subsidiary slip along-strike in the segment of the graben analysed, they would not influence our results significantly. Theoretically, considering these neglected components of fault displacement should increase the gouge sealing potential of the faults analysed.

Considering the simplification of our fault model, limitations of the dataset, and the qualitative character of fault seal potential, our results should be treated with caution and used only at the initial site screening stage of storage localization. They can be used e.g. for planning future research if the investigated site is considered for development. A crucial issue will be the calibration of sealing potential with permeability data and estimation of fault zone thickness (Torabi et al., 2020), to make the analysis more quantitative and useful in the flow modelling of injected fluid. All these components of fault sealing potential, not present in our general level analysis, should be included at the storage site characterization stage.

\section{CONCLUSIONS}

Based on industrial 3D seismic and borehole data, we have built a tectonic model of the WKG and performed a rough analysis of the fault sealing potential.

The WKG originated during the deposition of the Upper Triassic-Lower Jurassic strata. The regional context indicates that the WKG belongs to a group of grabens forming a horse-tail pattern, probably formed due to the accommodation of dextral strike-slip at the Wolin-Drawsko fault zone.

Comparison of fault orientations at the base of Zechstein (NW-SE strike) and in the Mesozoic succession (NNW-SSE strike) shows a discrepancy, which is explained by a transtensional graben above a dextral strike-slip fault in the Paleozoic basement.

The WKG is an asymmetrical structure, with the maximum throw (exceeding $1000 \mathrm{~m}$ ) on the main eastern boundary fault, and the subsidiary western fault attaining $600 \mathrm{~m}$ throw. The southern segment of the western boundary fault experienced inversion to a reverse character, most probably in the Late Cretaceous compressional event.

The main graben-bounding fault is entirely compensated within the Zechstein salt deposits (Na2 and Na3). Fault compensation led to the development of a depression in the western flank of the WKG and a salt pillow in the eastern flank of the graben. A local salt breakthrough at the base of the Triassic is interpreted in the middle segment of the eastern boundary fault.

In the Mesozoic succession, the best reservoirs are in the Jurassic sequence, in the Hettangian, Pliensbachian, and Bajocian sandstones separated by sealing shale horizons.

Our qualitative analyses of fault sealing potential was assessed separately for the juxtaposition and the fault gouge seals. We infer that: (1) the Hettangian reservoir is perfectly sealed on the main eastern fault by the juxtaposition component and moderately sealed by the fault gouge, while at the western boundary fault the juxtaposition seal is uncertain due to the unknown properties of the Muschelkalk limestone and a moderate fault gouge seal; (2) the Pliensbachian reservoir has both sealing potential components uncertain from the eastern side and non-effective from the western side; (3) the uppermost Bajocian 
reservoir lacks seals from both sides of the graben margin. The decrease in the fault sealing potential upwards is related to a gradual decrease in fault throw, due to successive graben infill by sediments.

From the above, we conclude that only the lower Jurassic reservoir can be potentially confined within the WKG. This reservoir seems to have a large thickness, low clay mineral content, and regional extent, which make it a potential storage site option. However, the lack of good quality sealing caprock directly above the reservoir may prevent full gas re-extraction from a repository. Therefore, the $\mathrm{CO}_{2}$ storage option is more realistic, especially given that the depth of this reservoir (1500 m) is sufficient to keep $\mathrm{CO}_{2}$ in the supercritical state.
Acknowledgements. The study is part of a project that has received funding by the European Union's Horizon 2020 research and innovation programme under grant agreement number 731166 (Hazard and Impact Knowledge for Europe - HIKE). Scientific work is co-funded by the geological surveys and national funds allocated for science within the period 2018-2021. We are grateful to the Polish Oil and Gas Co. for providing the seismic data and to Schlumberger for providing the Petrel software for performing the interpretation. We thank the reviewers $A$. Malz and $A$. Konon for their valuable comments and for providing advice on how to improve the manuscript.

\section{REFERENCES}

Allan, U.S., 1989. Model for hydrocarbon migration and entrapment within faulted structures. AAPG Bulletin, 73: 803-811.

Asquith, G., Krygowski, D., 2004. Basic relationships of well log interpretation. AAPG Methods in Exploration, 16: 1-20.

Aydin, A., 2000. Fractures, faults, and hydrocarbon entrapment, migration and flow. Marine and Petroleum Geology, 17: 797-814.

Barton, C.A., Zoback, M.D., Moos, D., 1995. Fluid flow along potentially active faults in crystalline rock. Geology, 23: 683-686.

Bojarski, L., Pazdro, J., Sobol, K., 1977. Anomalous reservoir pressures in the Polish Lowlands (in Polish with English summary). Przegląd Geologiczny, 25: 312-316.

Bouvier, J.D., Kaars-Sijpesteijn, C.H., Kluesner, D.F., Onyejekwe, C., Van Der Pal, R.C., 1989. Three-dimensional seismic interpretation and fault sealing investigations, Nun River Field, Nigeria. AAPG Bulletin, 73: 1397-1414.

Bredehoeft, J.D., Belitz, K., Sharp-Hansen, S., 1992. The hydrodynamics of the Big Horn Basin: a study of the role of faults. AAPG Bulletin, 76: 530-546.

Bretan, P., 2017. Trap Analysis: an automated approach for deriving column height predictions in fault-bounded traps. Petroleum Geoscience, 23: 56-69.

Bretan, P., Yielding, G., Jones, H., 2003. Using calibrated shale gouge ratio to estimate hydrocarbon column heights. AAPG Bulletin, 87: 397-413.

Caumon, G., Collon-Drouaillet, P., Le Carlier de Veslud, C., Viseur, S., Sausse, J., 2009. Surface-based 3D modeling of geological structures. Mathematical Geosciences, 4: 927-945.

Celia, M.A., Bachu, S., Nordbotten, J.M., Bandilla, K.W., 2015. Status of $\mathrm{CO}_{2}$ storage in deep saline aquifers with emphasis on modeling approaches and practical simulations. Water Resources Research, 51: 6846-6892.

Chen S., Xu S., Wang, D., Tan, Y., 2013. Effect of block rotation on fault sealing: An example in Dongpu sag, Bohai Bay basin, China. Marine and Petroleum Geology, 39: 39-47.

Childs, C., Manzocchi, T., Walsh, J.J., Bonson, C.G., Nicol, A., Schöpfer, M.P.J., 2009. A geometric model of fault zone and fault rock thickness variations. Journal of Structural Geology, 31: 117-127.

Clavier, C., Hoyle, W., Meunier, D., 1971. Quantitative interpretation of thermal neutron decay time logs: Part I. Fundamentals and techniques. Journal of Petroleum Technology, 23: 743-755.

Corona, F.V., Davis, J.S., Hippler, S.J., Vrolijk, P.J., 2010. Multi-fault analysis scorecard: testing the stochastic approach in fault seal prediction. Geological Society Special Publications, 347: 317-332.

Dadlez, R., 1989. Epicontinental Permian and Mesozoic basins in Poland (in Polish with English summary). Kwartalnik Geologiczny, 33 (2): 175-198.

Dadlez, R., 1990. Tectonics of the Southern Baltic (in Polish with English summary). Kwartalnik Geologiczny, 34 (1): 1-20
Dadlez, R., Jóźwiak, W., Młynarski, S., 1997. Subsidence and inversion in the western part of Polish Basin - data from seismic velocities. Geological Quarterly, 41 (2): 197-208.

Dadlez, R., Marek, S., 1997. Development of the Permian and Mesozoic basins (in Polish with English summary). Prace Państwowego Instytutu Geologicznego, 153: 403-409.

Dadlez, R., Marek, S., Pokorski, J., 2000. Geological Map of Poland Without Cenozoic Deposits. Państwowy Instytut Geologiczny, Warszawa.

Delprat-Jannaud, F., Korre, A., Shi, J.Q., McConnell, B., Arvanitis, A., Boavida, D., Car, M., Gastine, M., Grunnaleite, I., Bateman, K., Poulsen, N., Sinayuc, C., Vähäkuopus, T., Verceli, S., Wójcicki, A., 2013. State-of-the-art of review $\mathrm{CO}_{2}$ Storage Site Selection and Characterisation Methods. CGS Europe report No. D3.3 (eds. A. Korre, B. McConnell and F. Delprat-Jannaud), September 2013.

Doornenbal, H., Stevenson, A., (eds.), 2010. Petroleum Geological Atlas of the Southern Permian Basin Area. EAGE Publications, Houten.

Downey, M.W., 1984. Evaluating seals for hydrocarbon accumulations. AAPG Bulletin, 68: 1752-1763.

Feldman-Olszewska, A., 1997. Depositional architecture of the Polish epicontinental Middle Jurassic basin. Geological Quarterly 41 (4): 491-508.

Feldman-Olszewska, A., Adamczak, T., Szewczyk, J., 2010. Geological characterization of the reservoir and seal levels in the Zaosie and Jeżów structures as a candidate site for $\mathrm{CO}_{2}$ storage on the basis of the data from deep boreholes (in Polish with English summary). Biuletyn Państwowego Instytutu Geologicznego, 439: $17-28$

Feldman-Olszewska, A., Adamczak-Biały, T., Becker, A., 2012. Characterization of the Jurassic and Triassic reservoirs and seals from north Mazovia as a candidate site for $\mathrm{CO}_{2}$-storage based on data from deep boreholes (in Polish with English summary). Biuletyn Państwowego Instytutu Geologicznego, 448: $27-46$.

Fisher, Q.J., Knipe, R.J., 1998. Fault sealing processes in siliciclastic sediments. Geological Society Special Publications, 147: $117-134$

Fort, X., Brun, J.-P., Chauvel, F., 2004. Salt tectonics on the Angolan margin, synsedimentary deformation processes. AAPG Bulletin, 88: 1523-1544.

Foxford, K.A., Walsh, J.J., Watterson, J., Garden, I.R., Giscott, S.C., Burley, S.D., 1998. Structure and content of the Moab Fault Zone, Utah, USA, and its implications for fault seal prediction. Geological Society Special Publications, 147: 87-103.

Fristad, T., Groth, A., Yielding, G., Freeman, B., 1997. Quantitative fault seal prediction: a case study from Oseberg Syd. Norwegian Petroleum Society Special Publications, 7: 107-124.

Fulljames, J.R., Zijerveld, L.J.J., Franssen, R.C.M.W., 1997 Fault seal processes: systematic analysis of fault seals over 
geological and production time scales. Norwegian Petroleum Society Special Publications, 7: 51-61.

Gajewska, I., 1988. Palaeothickness and lithofacies of the Muschelkalk and lower Keuper and the middle Triassic palaeotectonics in Polish Lowland (in Polish with English summary). Kwartalnik Geologiczny, 32 (1): 73-82.

Gibson, R., 1994. Fault-zone seals in siliciclastic strata of the Columbus Basin, offshore Trinidad. AAPG Bulletin, 78: 1372-1385.

Grunau, H.R., 1987. A worldwide look at the cap-rock problem. Journal of Petroleum Geology, 10: 245-265.

Hesthammer, J., Fossen, H., 2000. Uncertainties associated with fault sealing analysis. Petroleum Geoscience, 6: 37-45.

Hurst, A., 1987. Mineralogical analysis and the evaluation of the petrophysical parameter Vshale for reservoir description. Marine and Petroleum Geology, 4: 82-91.

Jackson, M., Hudec, M., 2017. Salt Tectonics: Principles and Practice. Cambridge.

Jarosiński, M., Beekman, F., Bada, G., Cloetingh, S., 2006. Redistribution of recent collision push and ridge push in Central Europe: insights from FEM modelling. Geophysical Journal International, 167: 860-880.

Jolley, S.J., Fisher, Q.J., Ainsworth, R.B., 2010. Reservoir compartmentalization: an introduction. Geological Society Special Publications, 347: 1-8.

Kemper, M., Gunning, J., 2014. Joint Impedance and Facies Inversion-Seismic inversion redefined. First Break, 32: 89-95.

Kim, Y.-S., Peacock, D.C.P., Sanderson, D.J., 2004. Fault damage zones. Journal of Structural Geology, 26: 503-517.

Kim, Y.-S., Sanderson, D.J., 2006. Structural similarity and variety at the tips in a wide range of strike-slip faults: a review. Terra Nova, 18: 330-344.

Knai, T.A., Knipe, R.J., 1998. The impact of faults on fluid flow in the Heidrun Field. Geological Society Special Publications, 147: 269-282.

Knipe, R.J., 1997. Juxtaposition and seal diagrams to help analyze fault seals in hydrocarbon reservoirs. AAPG Bulletin, 81: 187-195.

Knipe, R.J., 1993. The influence of fault zone processes and diagenesis on fluid flow. AAPG Studies in Geology, 36: 135-151.

Knipe, R.J., 1992. Faulting processes and fault seal. Norwegian Petroleum Society Special Publications, 1: 325-342.

Knipe, R.J., Fisher, Q.J., Jones, G., Clennell, M.R., Farmer, A.B., Harrison, A., Kidd, B., Mcallister, E., Porter, J.R., White, E.A., 1997. Fault seal analysis: successful methodologies, application and future directions. Norwegian Petroleum Society Special Publications, 7: 15-38.

Knott, S.D., 1993. Fault seal analysis in the North Sea. AAPG Bulletin, 77: 778-792.

Kopik, J., 1997. Jura środkowa: formalne i nieformalne jednostki litostratygraficzne (in Polish). Prace Państwowego Instytutu Geologicznego, 153: 263-264

Kopik, J., 1998. Lower and Middle Jurassic of the north-eastern margin of the Upper Silesian Coal Basin (in Polish with English summary). Biuletyn Państwowego Instytutu Geologicznego, 378: 67-129.

Krzywiec, P., 2006a. Triassic-Jurassic evolution of the Pomeranian segment of the Mid-Polish Trough-basement tectonics and subsidence patterns. Geological Quarterly, 50 (1): 139-150.

Krzywiec, P., 2006b. Structural inversion of the Pomeranian and Kuiavian segments of the Mid-Polish Trough - lateral variations in timing and structural style. Geological Quarterly, 50 (1): 151-168.

Kwolek, K., 2000. The age of tectonic movements in the PoznańKalisz dislocation zone, Fore-Sudetic Monocline (in Polish with English summary). Przegląd Geologiczny, 48: 804-814.

Labaume, P., Moretti, I., 2001. Diagenesis-dependence of cataclastic thrust fault zone sealing in sandstones. Example from the Bolivian Sub-Andean Zone. Journal of Structural Geology, 23: $1659-1675$.

Lindsay, N.G., Murphy, F.C., Walsh, J.J., Watterson, J., 1993. Outcrop studies of shale smears on fault surfaces. IAS Special Publication, 15: 113-123.

Manzocchi, T., Heath, A.E., Palananthakumar, B., Childs, C., Walsh, J.J., 2008. Faults in conventional flow simulation mod- els: a consideration of representational assumptions and geological uncertainties. Petroleum Geoscience, 14: 91-110.

Mauduit, T., Brun, J.P., 1998. Growth fault/rollover systems: Birth, growth, and decay. Journal of Geophysical Research, 103 (B8): 18119-18136.

McClay, K.R., Waltham D.A., Scott, A.D., Abousetta, A.A., 1991 Physical and seismic modelling of listric normal fault geometries. Geological Society Special Publications, 56: 231-239.

Mildren, S.D., Hillis, R.R., Kaldi, J., 2002. Calibrating predictions of fault seal reactivation in the Timor sea. The APPEA Journal, 42: $187-202$

Moretti, I., 1998. The role of faults in hydrocarbon migration. Petroleum Geoscience, 4: 81-94.

Murray, T.A., Power, W.L., Johnson, A.J., Christie, G.J., Richards, D.R., 2019. Validation and analysis procedures for juxtaposition and membrane fault seals in oil and gas exploration. Geological Society Special Publications, 496: 145-161.

Needham, D.T., Yielding, G., Freeman, B., 1996. Analysis of fault geometry and displacement patterns. Geological Society Special Publications, 99: 189-199.

Pandey, V., Nekrasova, T., Tsybulkina, I., Clemons, K., Li, D., Six, B., 2020. Prediction of 3-D Facies and Petrophysical Models using Seismic Inversion and Advanced Statistical Data Analytics in Midland Basin Study Area. SPE/AAPG/SEG Unconventional Resources Technology Conference, Virtual, July 2020. Paper Number: URTEC-2020-2442-MS

Pei, Y., Paton, D.A., Knipe, R.J., Wu, K., 2015. A review of fault sealing behaviour and its evaluation in siliciclastic rocks. EarthScience Reviews, 150: 121-138.

Pieńkowski, G., 2004. The epicontinental Lower Jurassic of Poland. Polish Geological Institute Special Papers, 12: 5-154.

Pożaryski, W., Dadlez, R., 1987. Tectonics (in Polish with English summary). Prace Państwowego Instytutu Geologicznego, 119: 175-194.

Serra, O., 1984. Fundamentals of Well-log Interpretation. Elsevier, Amsterdam.

Shipton, Z.K., Evans, J.P., Thompson, L.B., 2005. The geometry and thickness of deformation-band fault core and its influence on sealing characteristics of deformation-band fault zones. AAPG Memoir, 85:181-195.

Smith, D.A., 1966. Theoretical considerations of sealing and non-sealing faults. AAPG Bulletin, 50: 363-374.

Sowiżdżał, A., Semyrka, R., 2016. Analyses of permeability and porosity of sedimentary rocks in terms of unconventional geothermal resource explorations in Poland. Geologos, 22: 149-163.

Stieber, S.J., 1970. Pulsed Neutron Capture Log Evaluation - Louisiana Gulf Coast. Society of Petroleum Engineers, SPE 2961.

Stephenson, R.A., Narkiewicz, M., Dadlez, R., van Wees, J.D., Andriessen, P., 2003. Tectonic subsidence modelling of the Polish Basin in the light of new data on crustal structure and magnitude of inversion. Sedimentary Geology, 156: 59-70.

Szewczyk, J., 2000. Statistical-stratigraphic standardization of natural gamma radiation well logs (in Polish with English summary). Biuletyn Państwowego Instytutu Geologicznego, 392: 121-152.

T7 SEAL modules. In: http://www.badleys.co.uk/T7-SEAL.php

Torabi, A., Ellingsen, T.S.S., Johannessen, M.U., Alaei, B., Rotevatn, A., Chiarella, D., 2020. Fault zone architecture and its scaling laws: where does the damage zone start and stop? Geological Society Special Publications, 496: 99-124.

Torabi, A., Johannessen, M.U., Ellingsen, T.S.S., 2019. Fault core thickness: insights from siliciclastic and carbonate rocks. Geofluids, 2019: 1-24.

Vrolijk, P.J., Urai, J.L., Kettermann, M., 2016. Clay smear: review of mechanisms and applications. Journal of Structural Geology, 86: 95-152.

Wagner, R., Peryt, T.M., 1997. Possibility of sequence stratigraphic subdivision of the Zechstein in the Polish Basin. Geological Quarterly, 41 (4): 457-474.

Walderhaug, O., 1996. Kinetic modeling of quartz cementation and porosity loss in deeply buried sandstone reservoirs. AAPG Bulletin, 80: 731-745. 
Walsh, J.J., Watterson, J., 1988. Analysis of the relationship between displacements and dimensions of faults. Journal of Structural Geology, 10: 239-247.

Wang, M., Huang, K., Xie, W., Dai, X., 2019. Current research into the use of supercritical $\mathrm{CO}_{2}$ technology in shale gas exploitation. International Journal of Mining Science and Technology, 29: 739-744.

Watterson, J., 1986. Fault dimensions, displacements and growth. Pure and Applied Geophysics 124: 365-373.

Watts, N.L., 1987. Theoretical aspects of cap-rock and fault seals for single- and two-phase hydrocarbon columns. Marine and Petroleum Geology, 4: 274-307.

Weber, K.J., 1997. A historical overview of the efforts to predict and quantify hydrocarbon trapping features in the exploration phase and in field development planning. Norwegian Petroleum Society Special Publications, 7: 1-13.

Wójcicki, A., Jarosiński, M., Roman, M., 2021. The estimation of $\mathrm{CO}_{2}$ storage potential of a gas-bearing shale succession at the early stage of reservoir characterization: a case study from the Baltic Basin (Poland). Geological Quarterly, 65 (1): 3.
Yielding, G., Bretan, P., Freeman, B., 2010. Fault seal calibration: a brief review. Geological Society Special Publications, 347: 243-255.

Yielding, G., Freeman, B., Needham, D.T., 1997. Quantitative fault seal prediction. AAPG Bulletin, 81: 897-917.

Zhang, X., Sanderson, D.J., 1996. Numerical modelling of the effects of fault slip on fluid flow around extensional faults. Journal of Structural Geology, 18: 109-119.

Zheng, S.-Y., Corbett, P., Ryseth, A., Stewart, G., 2000. Uncertainty in well test and core permeability analysis: a case study in fluvial channel reservoirs, northern North Sea, Norway. AAPG Bulletin, 84: 1929-1954.

Ziegler, P.A. (ed.), 1992. Geological Atlas of Western and Central Europe, 2nd edition. Geological Society of London, Hague.

Zoback, M.D., 2007. Reservoir Geomechanics. Cambridge University Press, Cambridge.

Złoże ropy i koncesja Kamień Pomorski. In: salon24.pl https://www.salon24.pl/u/wnukowi/799339, zloze-ropy-i-koncesja-kamien-pomorski. Accessed 19 Nov 2020. 